\title{
Assessment of sediment toxicity in the Lagoon of Venice (Italy) using a multi-species set of bioassays
}

\author{
Marco Picone ${ }^{\mathrm{a}, \mathrm{b}}$, Martina Bergamin ${ }^{\mathrm{a}}$, Chiara Losso ${ }^{\mathrm{b}}$, Eugenia Delaney ${ }^{\mathrm{a}}$, \\ Alessandra Arizzi Novelli ${ }^{\mathrm{b}}$, Annamaria Volpi Ghirardini ${ }^{\mathrm{b}, \mathrm{c}, *}$ \\ a Thetis S.p.A., Castello 2737/f, I-30122 Venice, Italy \\ ${ }^{\mathrm{b}}$ Department of Environmental Sciences, Ca' Foscari University of Venice, Campo della celestia 2737/b, I-30122 Venice, Italy

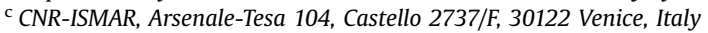

\section{A R T I C L E I N F O}

\section{Article history:}

Received 27 April 2015

Received in revised form

14 August 2015

Accepted 1 September 2015

Available online 26 September 2015

Keywords:

Sediment quality assessment

Toxicity bioassay

Corophium volutator

Paracentrotus lividus

Crassostrea gigas

\begin{abstract}
A B S T R A C T
Within the framework of a Weight of Evidence (WoE) approach, a set of four toxicity bioassays involving the amphipod Corophium volutator (10 d lethality test on whole sediment), the sea urchin Paracentrotus lividus (fertilization and embryo toxicity tests on elutriate) and the pacific oyster Crassostrea gigas (embryo toxicity test on elutriate) was applied to sediments from 10 sampling sites of the Venice Lagoon (Italy). Sediments were collected during three campaigns carried out in May 2004 (spring campaign), October 2004 (autumn campaign) and February 2005 (winter campaign). Toxicity tests were performed on all sediment samples. Sediment grain-size and chemistry were measured during spring and autumn campaigns. This research investigated (i) the ability of toxicity tests in discriminating among sites with different contamination level, (ii) the occurrence of a gradient of effect among sampling sites, (iii) the possible correlation among toxicity tests, sediment chemistry, grain size and organic carbon, and (iv) the possible occurrence of toxicity seasonal variability. Sediment contamination levels were from low to moderate. No acute toxicity toward amphipods was observed, while sea urchin fertilization was affected only in few sites in just a single campaign. Short-term effects on larval development of sea urchin and oyster evidenced a clear spatial trend among sites, with increasing effects along the axis connecting the sea-inlets with the industrial area. The set of bioassays allowed the identification of a spatial gradient of effect, with decreasing toxicity from the industrial area toward the sea-inlets. Multivariate data analysis showed that the malformations of oyster embryos were significantly correlated to the industrial contamination (metals, polynuclear aromatic hydrocarbons, hexachlorobenzene and polychlorinated biphenyls), while sea urchin development to sediment concentrations of As, $\mathrm{Cr}$ and organic carbon. Both embryo toxicity tests were significantly affected by high ammonia concentrations found in the elutriates extracted from some mudflat and industrial sediments. No significant temporal variation of the toxicity was observed within the experimental period. Amendments to the set of bioassays, with inclusion of chronic tests, can certainly provide more reliability and consistency to the characterization of the (possible) toxic effects.
\end{abstract}

๑) 2015 Elsevier Inc. All rights reserved.

\section{Introduction}

The Weight of Evidence (WoE) approach represents one of the more reliable tools for decision makers supporting the choice of the most suitable intervention strategies on contaminated sediment within an environmental risk assessment (ERA) framework (Burton et al., 2002; Chapman et al., 2002a; Micheletti et al., 2011). The effectiveness of the WoE approach depends largely on the

\footnotetext{
* Corresponding author at: Department of Environmental Sciences, Ca' Foscari University of Venice, Campo della celestia 2737/b, I-30122 Venice, Italy. Fax: + 390415281494.

E-mail address: voghi@unive.it (A.V. Ghirardini).
}

reliability of the methods used for assessing the single Line of Evidence (LoE), including sediment chemistry, benthic community structure analysis, toxicity testing, bioaccumulation and biomarkers (Chapman et al., 2002a, b; Chapman and Anderson, 2005).

Toxicity testing is one of the most critical LoE because it links exposure to contaminated sediment with the effects on the biota. Thus, it is mandatory the use of standardized and reliable methods as well multiple target species (reasonably similar to those living in the site of interest) and endpoints (e.g. survival, reproduction, growth and development) (Reynoldson et al., 2002; Chapman and Anderson, 2005, Carballeira et al., 2012; Aguirre-Martínez et al. 2015). 
In Venice Lagoon (Italy), several monitoring programs were carried out in the past decades investigating the state of the environment through an interdisciplinary approach. In most of the cases, toxicity testing and the other LoE, as water and sediment chemistry, benthic community and biomarkers were individually studied, or just integrated a posteriori within a comprehensive framework or partially analysed (Losso and Volpi Ghirardini, 2010). The three-year ICSEL project (Integrazione delle ConoScenze sull'Ecosistema Lagunare, 2003-2006) was the first study at the whole Venice Lagoon scale designed for the development of a WoE approach as screening-level ERA. Data on sediment chemistry, toxicity testing, bioaccumulation and biomarkers data collected in the period 2003-2005 were integrated following a multi-step decision making framework identifying the appropriate and site specific management actions to be adopted for the investigated sites (Chapman and Anderson, 2005).

The aim of this paper was to focus on toxicity testing and sediment chemistry. Sediment toxicity was investigated from May
2004 up to February 2005 (May 2004 (spring campaign), October 2004 (autumn campaign) and February 2005 (winter campaign) considering the following bioassays: i) the $10 \mathrm{~d}$ lethality test on whole sediment with the amphipod Corophium volutator (Pallas, 1766), ii) the sperm-cell and embryotoxicity tests with the sea urchin Paracentrotus lividus (Lamarck, 1816) on elutriates, and the embryotoxicity test with the pacific oyster Crassostrea gigas (Thunberg, 1793) on elutriates. International standard guidelines are available for the selected bioassays (USEPA, 2002; ASTM, 2004; ISO, 2005) and specific protocols were previously developed and validated for the application of the water-phase test in Venice Lagoon (Volpi Ghirardini and Arizzi Novelli, 2001, 2002, 2006; Losso et al., 2004; Volpi Ghirardini et al., 2005a). The applicability in Venice Lagoon of the amphipod standard protocol for sediment testing was already verified by Picone (2006) and Picone et al. (2008). Sediment were investigated for the presence of organic carbon (OC), metals, polynuclear aromatic hydrocarbons (PAH), organo-chlorine pesticides (OCP), hexachlorobenzene (HCB), poly-

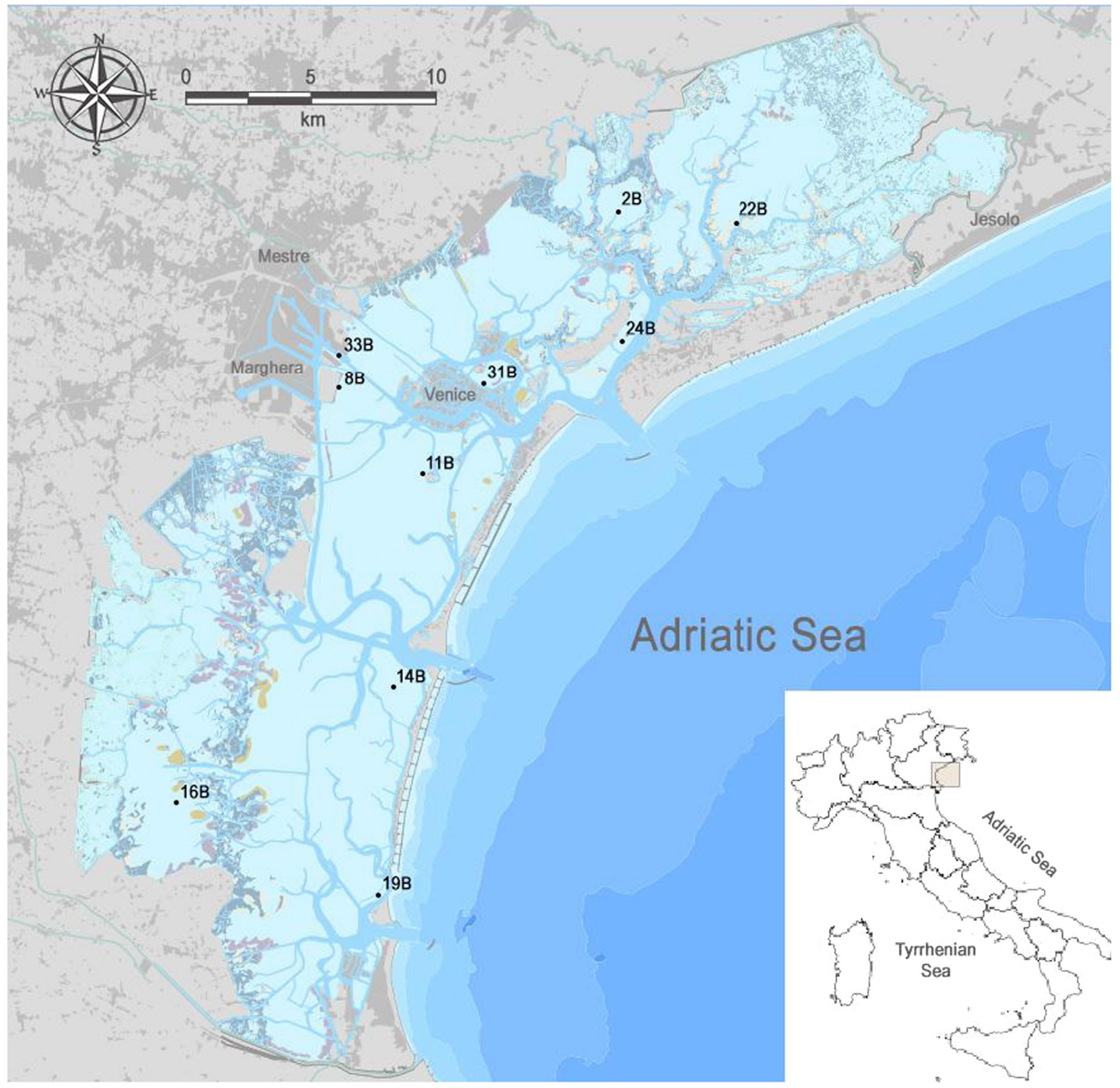

Fig. 1. Sampling sites position in the Lagoon of Venice. 
chlorinated biphenyls (PCB) and aliphatic hydrocarbons. Mean Probable Effect Level quotient (mPELq) was used as an index of overall contamination (Long et al., 2006). Results from toxicity tests were critically assessed for the WoE approach considering the performance of each bioassay. Toxicity and chemical data were also analysed to verify: (i) the test ability in discriminating between sites with different levels of contamination, (ii) the occurrence of a gradient of effects between the investigated sites, (iii) the (possible) occurrence of seasonal variations in toxicity effects, and (iv) the correlation between toxicity testing and sediment physico-chemical parameters establishing potential cause-effect relationships.

The ultimate goal of this research is to provide a knowledge base for the identification of the most reliable methods in order to set up an effective multi-species and multi-endpoints battery of ecotoxicity tests for Venice lagoon sediment. A reliable ecotoxicity testing battery for environmental monitoring should be a fundamental tool for decision support and planning of interventions (i.e. remediation of some areas, reuse of clean sediments for morphological recovery, improvements of wastewater cleaning processess, etc) in a complex environment such as the Venice Lagoon.

\section{Materials and methods}

\subsection{Area of study}

Ten sampling sites within the Lagoon of Venice (Fig. 1) were selected along a gradient of chemical contamination and toxicity, on the basis of previous studies and surveys (MAG.ACQUE-Thetis, 2006; Picone et al., 2008). Three sampling sites (14B - San Pietro in Volta, 19B - Caroman and 24B - Sant'Erasmo) are located near the sea-inlets and characterized by sandy sediments and low levels of contamination. Two sites (2B - Palude della Rosa and 22B Palude Maggiore) are located in silty and low contaminated mudflat areas in the Northern basin of Venice Lagoon potentially presenting high levels of naturally occurring sulphides and ammonia. The site $16 \mathrm{~B}$ - Valle Millecampi is located in a high-productive mudflat in the Southern basin of Venice Lagoon presenting silty sediments, high OC content and, potentially, high concentration of naturally occurring ammonia. The site 11B - Sacca Sessola, located in a shallow area of the central basin of Venice Lagoon, is potentially affected by urban contamination and sediment resuspension due to illegal clam fishing. The sampling site 31B - Fondamente Nove (F.te Nove) is located near to the Venice historical centre and is affected mainly by urban contamination coming from raw and partially treated sewage discharge and intense boat traffic. The last two sampling sites, 33B - Canale Industriale Nord and 8B - Tresse, are both affected by metal and organic contamination of industrial origin, being the first located within the industrial area of Porto Marghera and the second (8B) near to a dumping site for contaminated sediments dredged from the industrial channels.

\subsection{Sediment sampling and handling}

Surface sediments $(0-15 \mathrm{~cm}$ depth) were sampled in spring (May 2004), autumn (October 2004) and winter (February 2005), using a $5 \mathrm{~cm}$ diameter Plexiglas ${ }^{\mathrm{B}}$ corer, following an integrated sampling design developed under a quality assurance/quality control (QA/QC) program (Volpi Ghirardini et al., 2005b). Sediments were stored in 21 glass jars and kept at $4{ }^{\circ} \mathrm{C}$ in the dark. After their arrival in the laboratory, samples were thoroughly homogenized, dry sieved through a $1 \mathrm{~mm}$ mesh, stainless steel sieve and finally divided into aliquots for sediment testing, physico-chemical analyses and elutriate preparation.

\subsection{Elutriation}

Elutriates were prepared according to the protocol proposed by Volpi Ghirardini et al. (2005b). Briefly, wet sediment and artificial seawater (ASTM, 2004) were mixed at a ratio $1: 4 \mathrm{w} / \mathrm{v}$ ( $w=$ sediment dry weight; $v=$ water volume) and stirred for $24 \mathrm{~h}$ at $230 \mathrm{rpm}$ using a Jar Test (mod. JLT6, Velp Scientifica, Milan, Italy) at $4{ }^{\circ} \mathrm{C}$ in the dark. The slurry was allowed to settle for $60 \mathrm{~min}$ at $4{ }^{\circ} \mathrm{C}$ and then the supernatant was centrifuged at $7700 \mathrm{~g}$ for $15 \mathrm{~min}$ using a refrigerated centrifuge at $4{ }^{\circ} \mathrm{C}(\bmod$. Allegra 25R, Beckman Coulter, Fullerton, CA, USA). After centrifuging, elutriate samples were stored in polyethylene (PE) containers without filtering and then frozen at $-18{ }^{\circ} \mathrm{C}$ for toxicity testing. Only $50 \mathrm{ml}$ of samples were filtered through Whatman GF/F $0.7 \mu \mathrm{m}$ filters for subsequent total ammonia and sulphide analyses.

\subsection{Physico-chemical analyses}

Grain-size and sediment chemistry were measured during spring and autumn campaigns. Grain-size was determined following a gravimetric procedure (ICRAM, 2001). Total OC analyses were performed using a CHNS-O analyzer (mod. EA1110, CEInstruments, ThermoElectron, Milan, Italy) considering 10-20 mg of dry sediment acidified with $20 \mu \mathrm{L}$ of $1 \mathrm{~N} \mathrm{HCl}$ solution and dried at $105^{\circ} \mathrm{C}$ for $15 \mathrm{~min}$.

Total ammonia and sulphide concentrations were measured in elutriates using blue indophenols and methylene blue methods, respectively (Fonselius, 1969; APAT, 2003).

Dry weight total metals concentrations were performed using inductively coupled plasma - atomic emission spectrometry (ICP$\mathrm{AES}$ ) for $\mathrm{Cr}, \mathrm{Cu}, \mathrm{Ni}$ and $\mathrm{Zn}$ (EPA method 6010B); atomic absorption - furnace technique for As, Cd and Pb (EPA methods 7060A, 7131B and 7421, respectively) and atomic absorption spectrophotometry for $\mathrm{Hg}$ (EPA method 7473). Prior to analyses, samples were digested through a microwave assisted acid digestion (EPA method 3052). Simultaneously, extracted metals (SEM) and acid volatile sulphides (AVS) were determined (Allen and Deng, 1993). Aliphatic hydrocarbons of less than 12 carbon atoms $(\mathrm{HC}<12)$ were analysed by gas chromatography/mass spectrometry following EPA method 8260B. The EPA method 8270D was used for long-chain aliphatic hydrocarbons $(\mathrm{HC}>12)$. Prior to analysis, samples were prepared according to the EPA method $5021(\mathrm{HC}<12)$ and $3550 \mathrm{C}$ (HC > 12).

PAHs were measured via high-resolution gas chromatography/ high-resolution mass spectrometry (HRGC/HRMS) following the EPA method 0610. PCB congeners were determined by HRGC/ HRMS following the EPA method 1668A. OCPs and HCB analyses were carried out using gas chromatography (EPA method 8081B) after ultrasonic extraction (EPA method 3550C). An estimation of the potential synergistic effects due to the contaminants measured in sediment was obtained by calculating the mPELq for each sample (Long et al., 2006).

\subsection{Toxicity tests}

\subsection{1. $10 \mathrm{~d}$ whole sediment mortality tests with the amphipod $\mathrm{C}$. volutator}

The $10 \mathrm{~d}$ whole sediment tests were performed following the ISO standard method (ISO, 2005), the only modification being the number of amphipods used per replicate (25 instead of 20) and the number of replicates ( 4 instead of 5 ). The specimens of $C$. volutator (mud shrimp) were purchased from Guernsey Sea Farms Ltd (Vale, Guernsey, United Kingdom) and shipped overnight to the laboratory by express courier. After their arrival, organisms were gradually acclimated to the test condition $\left(T=15^{\circ} \mathrm{C}\right.$; salinity $=32 \mathrm{psu}$; $\mathrm{pH}=7.5-8.5)$ under constant aeration and continuous light (500- 
$1000 \mathrm{~lx}$ ) using native sediment as substrate. Acclimation of amphipods to toxicity test temperature and salinity occurred at a maximum rate of $3{ }^{\circ} \mathrm{C}$ and 3 psu per day. Once the test salinity and temperature were reached, the organisms were kept under those conditions for at least $72 \mathrm{~h}$ before testing. The acclimation period was no longer than 10 days. Temperature, $\mathrm{pH}$, salinity and ammonia of the overlying water were checked at the beginning and at the end of the tests in all the test chambers. The artificial seawater used as dilution water was obtained by dissolving a commercial salt mixture $\left(\mathrm{NaCl}, \mathrm{MgSO}_{4} \cdot 7 \mathrm{H}_{2} \mathrm{O}, \mathrm{MgCl}_{2} \cdot 6 \mathrm{H}_{2} \mathrm{O}, \mathrm{KCl}\right.$, $\mathrm{NaHCO}_{3}, \mathrm{KBr}, \mathrm{Na}_{2} \mathrm{CO}_{3}, \mathrm{H}_{3} \mathrm{BO}_{3}, \mathrm{SrCl}_{2} \cdot 6 \mathrm{H}_{2} \mathrm{O}, \mathrm{KF}, \mathrm{KI}$, and $\mathrm{CaCl}_{2} \cdot 2 \mathrm{H}_{2} \mathrm{O}$, Ocean Fish, Prodac International, Cittadella, Italy) in Milli- $Q^{\mathrm{K}}$ purified water (Millipore, Bedford, MA, USA). According to the intra-laboratory $\mathrm{QA} / \mathrm{QC}$ procedure, a negative control with native sediment and a positive control test (water only exposure) with cadmium (Cd) as reference toxicant were carried out in parallel with each session of sediment testing (Cd concentrations tested: $0.8,1.6,3.2,6.4$ and $12.8 \mathrm{mg} / \mathrm{L}$ of $\mathrm{Cd}$ ).

\subsubsection{Sperm cell and embryo toxicity test with the sea urchin $P$. lividus}

Scuba divers collected adult sea urchins on rocky seashores along the northern Tyrrhenian coast (Tuscany, Italy) far from industrial and agricultural discharges (Lera et al., 2006; ARPAT, 2013). The organisms were then immediately transported to the laboratory using an insulating container filled with sampling site water and kept under constant aeration. In the laboratory, the sea urchins were held in a 3001 glass aquarium filled with flowing natural seawater and progressively acclimatised to test conditions $\left(T=18 \pm 1{ }^{\circ} \mathrm{C}\right.$, salinity $\left.=35 \pm 1 \mathrm{psu}\right)$ under natural photoperiod. The sperm cell and embryotoxicity test were performed according to Volpi Ghirardini and Arizzi Novelli (2001) and Arizzi Novelli et al. (2002). Briefly, adults were induced to spawn by injecting $1 \mathrm{~mL}$ of $0.5 \mathrm{M} \mathrm{KCl}$ solution through the peristomal membrane. Pools of gametes from at least 3 males and 3 females were collected. The density of sperm cell and egg suspensions were adjusted to $4 \cdot 10^{7}$ cells $/ \mathrm{mL}$ and 2000 cells $/ \mathrm{mL}$, respectively. For the sperm cell test, $0.1 \mathrm{~mL}$ of sperm cell suspension were inoculated in $10 \mathrm{~mL}$ of test solution. After $60 \mathrm{~min}, 1 \mathrm{~mL}$ of egg suspension was added and the test lasted for other 20 min before fixing with buffered formalin. For the embryotoxicity test, fertilization was performed in artificial seawater at a sperm:egg ratio of 20,000:1. A volume of $1 \mathrm{~mL}$ of fertilized egg suspension was added to $10 \mathrm{ml}$ of test solution and incubated in the dark at $18{ }^{\circ} \mathrm{C}$ for $72 \mathrm{~h}$. Spermcells and embryos were exposed to at least 4 elutriate dilutions $(25 \%, 50 \%, 75 \%, 100 \%)$ in sterile polystyrene six-wells micro-plates with lids as test chambers (Iwaki, Asashi Techno Glass, Tokyo, Japan) using 3 replicates per dilution. Dilution water was prepared using reagent grade salts and Milli- $Q^{\mathbb{R}}$ purified water (ASTM, 2004). Positive control tests with copper (Cu) as reference toxicant were carried out simultaneously (Cu concentrations tested: 24, 36,
$48,60,72,84,96 \mu \mathrm{g} / \mathrm{L})$.

\subsubsection{Embryotoxicity test with the oyster $C$. gigas}

Conditioned adults of $C$. gigas were purchased from Guernsey Sea Farms Ltd (Vale, Guernsey, UK) and shipped overnight to the laboratory where they were used immediately after their arrival without holding or acclimation. Tests were performed following the procedure reported by Volpi Ghirardini et al. (2005a). Oysters were induced to spawn by thermal stimulation, alternating temperature cycles at $18^{\circ} \mathrm{C}$ and $28^{\circ} \mathrm{C}$. Gametes from the best males and females (at least 3 individuals for each sex were pooled) were selected and filtered using $32 \mu \mathrm{m}$ (sperm) and $100 \mu \mathrm{m}$ (eggs) mesh size sieves to remove impurities. Filtered eggs were collected into a $1000 \mathrm{~mL}$ graduated glass cylinder and subsequently fertilized by injecting $10 \mathrm{~mL}$ of filtered sperm suspension. Fertilized egg density was determined by counting four subsamples of $100 \mu \mathrm{L}$ under an inverted microscope; fertilized eggs were then added to test solutions in order to obtain a final density of 60-70 eggs/mL. Incubation lasted $24 \mathrm{~h}$ at $24^{\circ} \mathrm{C}$, then the content of each test chamber was fixed with buffered formalin. Embryos were exposed to six elutriate dilutions $(6 \%, 12 \%, 25 \%, 50 \%, 75 \%$ and $100 \%$ ) in sterile polystyrene 24 wells microplates with lids (Iwaki, Asashi Techno Glass, Tokyo, Japan). Three replicates per dilution were used. Dilution water was ASTM (2004). Positive control tests with $\mathrm{Cu}$ as reference toxicant were carried out ( $\mathrm{Cu}$ concentrations tested: $3,6,12,18,24,30,36$ and $42 \mu \mathrm{g} / \mathrm{L})$.

\subsection{Data analysis}

All toxicity data were shown as "normalized percentage of success" $(S)$, calculated as the percentage of success (i.e. \% of survival, \% of fertilized eggs, \% of normally developed plutei or Dshaped larvae) in the sample relative to percentage of success in the control.

For sea urchin and oyster toxicity tests, the results were also reported as Effective Concentration $50\left(\mathrm{EC}_{50}\right)$, when calculable. All data were subsequently reported as toxicity units (TU), calculated as $(100-S) / 50$ or $100 / \mathrm{EC}_{50}$ respectively. $\mathrm{LC} / \mathrm{EC}_{50}$ with $95 \%$ confidence limits for reference toxicants and elutriate tests were calculated using the Trimmed Spearman-Karber method v1.5.

Amphipod data were classified using the score reported for $C$. orientale (Picone et al., 2008), but modified using specie-specific toxicity thresholds that were calculated for $C$. volutator following the procedure outlined in Thursby et al. (1997). Embryotoxicity data both for sea urchins and oysters were ranked following the scores previously reported for the same species (Losso et al., 2007a). Toxicity classification criteria are summarized in Table 1; all toxicity scores and toxicity thresholds were based on the Minimum Significant Difference (MSD) criterion (Thursby et al., 1997; Phillips et al., 2001).

One-way ANOVA and Fisher post-hoc test were used to check

Table 1

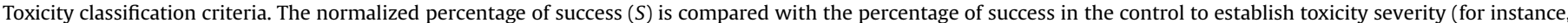

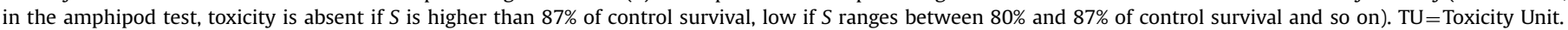

\begin{tabular}{|c|c|c|c|c|c|}
\hline \multirow[t]{2}{*}{ Test } & \multicolumn{5}{|l|}{ Toxicity classes } \\
\hline & Absent & Low & Medium & High & Very high \\
\hline C. volutator $10-\mathrm{d}$ lethality test $\mathrm{t}^{\mathrm{a}}$ & $S>87 \%$ control & $80 \%<S \leq 87 \%$ & $61 \%<S \leq 80 \%$ & $22 \%<S \leq 61 \%$ & $S \leq 22 \%$ \\
\hline P. lividus sperm-cell test $\mathrm{t}^{\mathrm{b}}$ & $S>92 \%$ control & $84 \%<S \leq 92 \%$ & $50 \%<S \leq 84 \%$ & $1 \leq \mathrm{TU}<2$ & $\mathrm{TU} \geq 2$ \\
\hline P. lividus embryo-toxicity test $\mathrm{t}^{\mathrm{C}}$ & $S>89 \%$ control & $50 \%<S \leq 89 \%$ & $1 \leq \mathrm{TU}<2$ & $2 \leq \mathrm{TU}<4$ & $\mathrm{TU} \geq 4$ \\
\hline C. gigas embryo-toxicity test ${ }^{\mathrm{C}}$ & $S>92 \%$ control & $50 \%<S \leq 92 \%$ & $1 \leq \mathrm{TU}<2$ & $2 \leq \mathrm{TU}<4$ & $\mathrm{TU} \geq 4$ \\
\hline
\end{tabular}

\footnotetext{
a This work.

b Picone (2006).

c Losso et al. (2007a)
} 
the statistical significant difference between reference condition and sediment sampling sites. Temporal and spatial trends among sites during the whole testing period were investigated using twoway ANOVA and Fisher post-hoc test. A set of a priori contrasts was used to test for statistical differences among the different areas of Venice Lagoon. Prior to ANOVA, data were transformed using arcsine square root transformation (amphipods) and logarithmic transformation (sea urchins and oysters). For sea urchins and oysters, log-transformed success data were used to check the differences from control, while log-transformed TU data were used to check for differences among sites. The two-way ANOVA was performed on log-transformed TU data for all the bioassays. Kolmogorov-Smirnov and Bartlett's tests were used to check for normality and variance homogeneity, respectively. When normality or variance homogeneity test failed, Kruskal-Wallis ANOVA on raw data was used.

Samples were considered as toxic only if the following two conditions were met: (i) statistical analysis highlighted significant difference from control $(\alpha=0.05)$ and (ii) the percentage of success normalised to control $(S)$ was lower than the toxicity limits calculated according to the MSD based toxicity scores (Phillips et al., 2001).

Multivariate analysis of the data was performed with the aim to evaluate correlations between biological effects and sediment chemistry; to this end, factor analysis using Principal Components (PC) as extraction procedure to reduce the dimensionality of the original set of variables was chosen. The raw data matrix was composed of the dry-weight sediment concentration of the analyzed chemicals, grain size, TOC, amphipod data reported as mortality, sea urchin and oyster data reported as TU. Principal Component Analysis (PCA) was performed on standardized data; factor rotation was performed using the varimax raw routine of the statistical software StatSoft Inc. Statistica 7.0 (Tulsa, OK, United States of America).

\section{Results}

\subsection{Physico-chemical analyses}

Ammonia and sulphide results on elutriates are reported in Table 2. Sulphides concentrations were very low $\left(S^{2-}<33 \mu \mathrm{g} / \mathrm{L}\right)$ in all the samples and were not of concern for toxicity effects according previous results (Arizzi Novelli et al., 2006; Losso et al., 2007b). In contrast, the level of total ammonia was higher than the reference benchmark values for the embryo toxicity test with sea urchin (3.1-4.2 mg/L) and oysters ( $4 \mathrm{mg} / \mathrm{L}$ ) in three sites (Arizzi Novelli et al. 2003; Losso et al., 2007b). The highest concentrations were detected during winter campaign, especially in sites $16 \mathrm{~B}$ and

Table 2

Sulphides and ammonia concentrations in elutriates. Ammonia concentrations are reported as total ammonia $\left(\mathrm{NH}_{3}+\mathrm{NH}_{4}{ }^{+}\right)$.

\begin{tabular}{|c|c|c|c|c|c|c|}
\hline \multirow[t]{2}{*}{ Sample } & \multicolumn{3}{|c|}{ Sulphides $(\mu \mathrm{g} / \mathrm{L})$} & \multicolumn{3}{|c|}{ Total ammonia $(\mathrm{mg} / \mathrm{L})$} \\
\hline & Spring & Autumn & Winter & Spring & Autumn & Winter \\
\hline $2 B$ & $<15$ & $<15$ & $<15$ & 2.95 & 4.83 & 1.59 \\
\hline $8 B$ & $<15$ & 29 & 32 & 1.10 & 3.73 & 3.23 \\
\hline 11B & 18 & 31 & 29 & 1.07 & 1.10 & 1.54 \\
\hline 14B & $<15$ & 16 & $<15$ & 1.27 & 0.85 & 1.68 \\
\hline $16 \mathrm{~B}$ & 33 & $<15$ & $<15$ & 0.42 & 2.80 & 10.41 \\
\hline 19B & $<15$ & $<15$ & $<15$ & 0.93 & 0.86 & 1.27 \\
\hline $22 \mathrm{~B}$ & $<15$ & 21 & $<15$ & 0.54 & 1.03 & 0.85 \\
\hline $24 \mathrm{~B}$ & $<15$ & $<15$ & $<15$ & 0.68 & 0.71 & 1.23 \\
\hline 31B & $<15$ & $<15$ & $<15$ & 1.08 & 1.16 & 1.22 \\
\hline 33B & $<15$ & $<15$ & $<15$ & 3.89 & 4.06 & 9.51 \\
\hline
\end{tabular}

$33 \mathrm{~B}$, while noteworthy concentrations were measured in sites $2 \mathrm{~B}$ in the autumn campaign; site 33B was generally characterized by high ammonia concentrations in all sampling campaigns.

The measured total concentrations of trace metals and organic micropollutants were shown in Table 3 together with the main physical parameters (TOC, particle size, and AVS). The sediment collected near the industrial area ( $8 \mathrm{~B}$ and $33 \mathrm{~B}$ ) were characterized by the highest concentrations of $\mathrm{As}, \mathrm{Cd}, \mathrm{Cu}, \mathrm{Hg}, \mathrm{Pb}, \mathrm{Zn}, \mathrm{PAHs}, \mathrm{PCBs}$ and $\mathrm{HCB}$. As regards to metals, $\mathrm{Hg}$ contamination was widespread in all basins, with several samples exceeding the Probable Effect Level (PEL) of $0.7 \mathrm{mg} / \mathrm{kg}$ dw (Mac Donald et al., 1996). Hg level did not exceed the PEL in the sampling sites located near the sea inlets (14B, 19B and 24B) and at 16B. Sediment collected near the city of Venice (31B) was characterized by the concentration of PAHs and PCBs similar to those detected in $8 \mathrm{~B}$ and $33 \mathrm{~B}$, whilst metal contamination, except for $\mathrm{Hg}$, was clearly less marked than that of samples $8 \mathrm{~B}$ and 33B. PAH and PCB contamination in 31B could be due to the intense boat traffic. OCPs were always below the detection limit ( $\mathrm{LOD}=0.1 \mu \mathrm{g} / \mathrm{Kg} \mathrm{dw}$ ). $\mathrm{HC}>12$ were found at low concentration in all sites showing a slight increment in the autumn campaign compared to the spring one; while $\mathrm{HC}<12$ were always below the LODs.

To evaluate the bioavailability of metals, the index ( $\Sigma$ SEM AVS $) / f_{\text {OC }}$ was used; the index is calculated as the difference between simultaneously extracted metals (SEM) and acid volatile sulphides (AVS) molar concentrations, normalized to the fraction of organic carbon in the sediments $\left(f_{\mathrm{OC}}\right)$. The index suggests that in most of the samples AVS concentrations exceed SEM concentrations, highlighting a limited bioavailability of the divalent cationic metals. The only exception to this trend was site 19B, where the AVS concentrations were very low compared to all other sediments. Since the value of the index $(\Sigma \mathrm{SEM}-\mathrm{AVS}) / f_{\mathrm{OC}}$ is less than the critical value of $130 \mu \mathrm{Mol} / \mathrm{g}$ of OC (USEPA, 2005) the occurrence of metal toxicity is unlikely.

The maximum mPELq calculated for the samples was 0.88 (33B, spring campaign); the relative low mPELq values found in the different areas of Venice Lagoon indicated that the sediment contamination is not of particular concern allowing their classification as lowest priority sites $(\mathrm{mPELq}<0.1)$ and medium-low priority sites $(0.11<\mathrm{mPELq}<1.5)$ (Long and MacDonald, 1997).

\subsection{Toxicity test}

\subsection{1. $10 \mathrm{~d}$ whole sediment mortality tests with the amphipod $\mathrm{C}$ volutator}

All the $\mathrm{LC}_{50}$ values with the reference toxicant $(\mathrm{Cd})$ were within the limits of the intra-laboratory control chart $(1.0-6.7 \mathrm{mg} / \mathrm{L}$ of $\mathrm{Cd}$, $n=17$ ), with a mean value \pm standard deviation of $3.5 \pm 0.8 \mathrm{mg} / \mathrm{L}$ $(n=8)$ in accordance with literature (Kater et al., 2000). The highest $\mathrm{LC}_{50}$ was found in October $(4.7 \mathrm{mg} / \mathrm{L})$, whilst the lower value was obtained in February $(2.0 \mathrm{mg} / \mathrm{L})$; no significant seasonal variation of amphipod sensitivity was evidenced during the testing period $(p=0.25)$. Mean survival in the control sediment was always $>90 \%$ ( $93 \pm 5.4 \%, n=32)$. Whole sediment mortality results on C. volutator are reported in Table 4. In the spring campaign, only in sample 14B amphipod survival resulted statistically different from the control, but it was characterized by a mean survival higher than the toxicity limit, so the effects were considered as negligible. In the autumn and winter campaigns, no significant differences was observed compared to the control.

The two-ways ANOVA indicated the absence of any seasonal $(p=0.06)$ and spatial $(p=0.50)$ variations of the toxicity for $C$. volutator.

\subsubsection{Sperm-cell test with the sea urchin P. lividus}

Eight tests with the reference toxicant were performed during 
Table 3

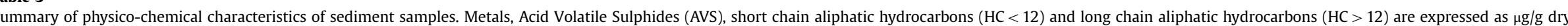

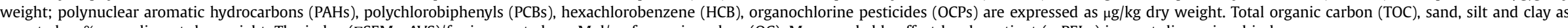
reported as \% on sediment dry weight. The index ( $\Sigma \mathrm{SEM}-\mathrm{AVS}) / \mathrm{f}_{\mathrm{oc}}$ is reported as $\mu \mathrm{Mol} / \mathrm{g}$ of organic carbon (OC). Mean probable effect level quotient (mPELq) is a not dimensional index.

\begin{tabular}{|c|c|c|c|c|c|c|c|c|c|c|c|c|c|c|c|c|c|c|c|c|}
\hline & \multicolumn{10}{|c|}{ Spring campaign } & \multicolumn{10}{|c|}{ Autumn campaign } \\
\hline & 2B & 8B & 11B & 14B & $16 B$ & 19B & 22B & 24B & 31B & 33B & 2B & 8B & 11B & 14B & 16B & 19B & 22B & 24B & 31B & 33B \\
\hline As & 8.6 & 17.9 & 7.4 & 5.3 & 16.6 & 5.1 & 6.3 & 5.7 & 4.2 & 18.7 & 11.7 & 20.4 & 8.8 & 7.6 & 14.6 & 5.3 & 7.4 & 7.7 & 8.2 & 23.5 \\
\hline Cd & 0.40 & 2.87 & 0.71 & 0.48 & 0.65 & 0.33 & 0.31 & 0.23 & 0.62 & 3.72 & 0.51 & 1.97 & 0.48 & 0.51 & 0.37 & 0.46 & 0.32 & 0.31 & 0.34 & 1.36 \\
\hline $\mathrm{Cr}$ & 48 & 40 & 40 & 39 & 64 & 39 & 43 & 21 & 25 & 58 & 42 & 52 & 29 & 30 & 54 & 36 & 35 & 19 & 21 & 46 \\
\hline $\mathbf{C u}$ & 25 & 46 & 21 & 14 & 26 & 7 & 18 & 9 & 22 & 73 & 22 & 61 & 16 & 20 & 34 & 7 & 19 & 8 & 74 & 41 \\
\hline $\mathrm{Hg}$ & 0.88 & 1.58 & 1.02 & 0.54 & 0.28 & 0.10 & 0.73 & 0.46 & 0.78 & 2.12 & 1.24 & 1.97 & 0.80 & 0.28 & 0.19 & 0.10 & 0.63 & 0.38 & 1.12 & 1.35 \\
\hline $\mathbf{N i}$ & 24 & 22 & 20 & 19 & 34 & 19 & 22 & 10 & 12 & 28 & 20 & 26 & 13 & 15 & 28 & 14 & 21 & 10 & 11 & 24 \\
\hline $\mathbf{P b}$ & 25 & 42 & 20 & 13 & 33 & 9 & 18 & 10 & 19 & 68 & 19 & 58 & 16 & 10 & 26 & 6 & 41 & 8 & 30 & 50 \\
\hline Zn & 94 & 382 & 121 & 82 & 150 & 49 & 72 & 52 & 116 & 464 & 73 & 406 & 81 & 52 & 101 & 34 & 56 & 43 & 85 & 292 \\
\hline HC $<12$ & $<0.1$ & $<0.1$ & $<0.1$ & $<0.1$ & $<0.1$ & $<0.1$ & $<0.1$ & $<0.1$ & $<0.1$ & $<0.1$ & $<0.1$ & $<0.1$ & $<0.1$ & $<0.1$ & $<0.1$ & $<0.1$ & $<0.1$ & $<0.1$ & $<0.1$ & $<0.1$ \\
\hline $\mathrm{HC}>12$ & 0.2 & 0.2 & 0.5 & 0.4 & 0.6 & 0.5 & 0.8 & 0.5 & 4.6 & 0.6 & 1.9 & 8.9 & 1.6 & 0.6 & 1.8 & 0.5 & 0.8 & 0.5 & 1.4 & 2.6 \\
\hline Total PAHs & 313 & 1147 & 395 & 101 & 510 & 82 & 178 & 256 & 4110 & 6354 & 230 & 5720 & 504 & 229 & 630 & 294 & 432 & 37 & 4902 & 5631 \\
\hline Total PCBs & 0.88 & 5.16 & 0.93 & 0.29 & 0.22 & 0.21 & 0.23 & 0.23 & 2.09 & 12.62 & 1.09 & 6.32 & 0.64 & 0.22 & 0.45 & 0.30 & 0.19 & 0.38 & 2.59 & 9.99 \\
\hline НСВ & $<0.05$ & 4.68 & 0.26 & 0.11 & 0.10 & 0.07 & $<0.05$ & $<0.05$ & 0.08 & 10.84 & 0.10 & 5.77 & 0.23 & 0.07 & 0.16 & 0.08 & 0.06 & 0.05 & 0.12 & 8.27 \\
\hline OCP & $<0.1$ & $<0.1$ & $<0.1$ & $<0.1$ & $<0.1$ & $<0.1$ & $<0.1$ & $<0.1$ & $<0.1$ & $<0.1$ & $<0.1$ & $<0.1$ & $<0.1$ & $<0.1$ & $<0.1$ & $<0.1$ & $<0.1$ & $<0.1$ & $<0.1$ & $<0.1$ \\
\hline TOC (\%) & 1.22 & 1.82 & 1.64 & 1.60 & 4.32 & 0.42 & 1.30 & 2.69 & 1.67 & 1.86 & 1.35 & 2.84 & 0.70 & 0.84 & 4.54 & 0.88 & 0.99 & 0.87 & 0.42 & 1.69 \\
\hline Sand (\%) & 2 & 25 & 16 & 45 & 27 & 88 & 4 & 56 & 27 & 5 & 4 & 20 & 15 & 50 & 22 & 92 & 4 & 57 & 24 & 6 \\
\hline Silt (\%) & 59 & 44 & 55 & 38 & 37 & 12 & 61 & 35 & 55 & 47 & 58 & 40 & 53 & 36 & 36 & 8 & 55 & 30 & 54 & 45 \\
\hline Clay (\%) & 39 & 31 & 29 & 17 & 36 & 0 & 35 & 9 & 18 & 48 & 38 & 40 & 32 & 14 & 42 & 0 & 41 & 13 & 22 & 49 \\
\hline AVS & 1342 & 273 & 191 & 103 & 51 & 3 & 403 & 25 & 132 & 206 & 476 & 196 & 149 & 102 & 194 & 39 & 143 & 72 & 214 & 576 \\
\hline $\begin{array}{l}(\Sigma \text { SEM }- \text { AVS }) / \\
f_{\text {Oc }}\end{array}$ & -3333 & -172 & -288 & -153 & -7 & 81 & -909 & -9 & -164 & 53 & -1041 & -106 & -545 & -316 & -110 & -100 & -401 & -208 & -1228 & -764 \\
\hline mPELq & 0.32 & 0.64 & 0.34 & 0.23 & 0.33 & 0.14 & 0.27 & 0.16 & 0.29 & 0.88 & 0.36 & 0.77 & 0.26 & 0.17 & 0.27 & 0.12 & 0.26 & 0.15 & 0.38 & 0.60 \\
\hline
\end{tabular}


Table 4

Summary of sediment toxicity test results. $\mathrm{EC}_{50}$ is given in \% elutriate (when calculable). $\mathrm{TL}=$ Toxicity limit. $\mathrm{TU}=$ Toxicity units.

\begin{tabular}{|c|c|c|c|c|c|c|c|c|c|c|c|c|c|c|c|c|c|c|c|c|c|c|}
\hline \multirow[t]{2}{*}{ Test } & \multirow[t]{2}{*}{ Site } & \multicolumn{7}{|c|}{ Spring campaign } & \multicolumn{7}{|c|}{ Autumn campaign } & \multicolumn{7}{|c|}{ Winter campaign } \\
\hline & & $S(\%)$ & Contr. & TL & $\mathrm{EC}_{50}$ & TU & $p$-value & $\begin{array}{l}\text { Toxicity } \\
\text { judgement }\end{array}$ & $S(\%)$ & Contr. & $\mathbf{T L}$ & $\mathrm{EC}_{50}$ & TU & $p$-value & $\begin{array}{l}\text { Toxicity } \\
\text { judgement }\end{array}$ & $S(\%)$ & Contr. & $\mathbf{T L}$ & $\mathrm{EC}_{50}$ & TU & $p$-value & $\begin{array}{l}\text { Toxicity } \\
\text { judgement }\end{array}$ \\
\hline \multirow{10}{*}{$\begin{array}{l}\text { C. volutator mortal- } \\
\text { ity test }\end{array}$} & $2 \mathrm{~B}$ & $100 \pm 2$ & 96 & 84 & & & 0.790 & Absent & $95 \pm 8$ & 95 & 83 & & & 0.282 & Absent & $100 \pm 5$ & 91 & 79 & & & 0.990 & Absent \\
\hline & $8 \mathrm{~B}$ & $100 \pm 4$ & 96 & 84 & & & 0.961 & Absent & $100 \pm 4$ & 90 & 78 & & & 0.954 & Absent & $99 \pm 3$ & 91 & 79 & & & 0.767 & Absent \\
\hline & $11 \mathrm{~B}$ & $93 \pm 7$ & 96 & 84 & & & 0.109 & Absent & $91 \pm 2$ & 90 & 78 & & & 0.133 & Absent & $100 \pm 6$ & 91 & 79 & & & 0.790 & Absent \\
\hline & $14 \mathrm{~B}$ & $90 \pm 4$ & 96 & 84 & & & 0.023 & Absent & $99 \pm 5$ & 90 & 78 & & & 0.812 & Absent & $98 \pm 14$ & 91 & 79 & & & 0.974 & Absent \\
\hline & $16 \mathrm{~B}$ & $96 \pm 3$ & 96 & 84 & & & 0.290 & Absent & $98 \pm 4$ & 90 & 78 & & & 0.655 & Absent & $100 \pm 9$ & 91 & 79 & & & 0.833 & Absent \\
\hline & $19 \mathrm{~B}$ & $99 \pm 8$ & 96 & 84 & & & 0.941 & Absent & $91 \pm 6$ & 90 & 78 & & & 0.141 & Absent & $100 \pm 5$ & 91 & 79 & & & 0.619 & Absent \\
\hline & $22 \mathrm{~B}$ & $97 \pm 7$ & 96 & 84 & & & 0.511 & Absent & $98 \pm 5$ & 95 & 83 & & & 0.634 & Absent & $97 \pm 4$ & 91 & 79 & & & 0.493 & Absent \\
\hline & $24 \mathrm{~B}$ & $97 \pm 5$ & 96 & 84 & & & 0.458 & Absent & $95 \pm 13$ & 95 & 83 & & & 0.398 & Absent & $100 \pm 4$ & 91 & 79 & & & 0.655 & Absent \\
\hline & 31B & $96 \pm 3$ & 96 & 84 & & & 0.290 & Absent & $99 \pm 7$ & 95 & 83 & & & 0.918 & Absent & $96 \pm 9$ & 91 & 79 & & & 0.482 & Absent \\
\hline & 33B & $100 \pm 6$ & 96 & 84 & & & 0.915 & Absent & $91 \pm 5$ & 95 & 83 & & & 0.047 & Absent & $98 \pm 7$ & 91 & 79 & & & 0.667 & Absent \\
\hline \multirow{10}{*}{$\begin{array}{l}\text { P. lividus sperm cell } \\
\text { test }\end{array}$} & $2 \mathrm{~B}$ & $92 \pm 1.2$ & 93 & 86 & & 0.16 & 0.106 & Absent & $99 \pm 5.5$ & 86 & 79 & & 0.02 & 0.791 & Absent & $96 \pm 3.3$ & 77 & 71 & & 0.08 & 0.339 & Absent \\
\hline & $8 \mathrm{~B}$ & $76 \pm 2.8$ & 93 & 86 & & 0.48 & $<\mathbf{0 . 0 0 1}$ & Medium & $94 \pm 2.9$ & 86 & 79 & & 0.12 & 0.209 & Absent & $100 \pm 0.7$ & 77 & 71 & & 0.00 & 0.064 & Absent \\
\hline & 11B & $87 \pm 2.2$ & 93 & 86 & & 0.26 & 0.013 & Absent & $100 \pm 4.3$ & 81 & 75 & & 0.00 & 0.79 & Absent & $94 \pm 1.3$ & 77 & 71 & & 0.12 & 0.17 & Absent \\
\hline & $14 \mathrm{~B}$ & $97 \pm 3.9$ & 93 & 86 & & 0.06 & 0.527 & Absent & $95 \pm 2.1$ & 81 & 75 & & 0.11 & 0.375 & Absent & $95 \pm 5.2$ & 77 & 71 & & 0.1 & 0.237 & Absent \\
\hline & $16 \mathrm{~B}$ & $92 \pm 2.8$ & 93 & 86 & & 0.16 & 0.139 & Absent & $94 \pm 4.0$ & 81 & 75 & & 0.12 & 0.3 & Absent & $99 \pm 6.4$ & 77 & 71 & & 0.02 & 0.731 & Absent \\
\hline & $19 \mathrm{~B}$ & $90 \pm 0.6$ & 93 & 86 & & 0.2 & 0.051 & Absent & $86 \pm 5.8$ & 86 & 79 & & 0.28 & 0.004 & Absent & $100 \pm 5.8$ & 77 & 71 & & 0.00 & 0.372 & Absent \\
\hline & $22 \mathrm{~B}$ & $87 \pm 4.5$ & 93 & 86 & & 0.26 & 0.015 & Absent & $97 \pm 3.8$ & 86 & 79 & & 0.06 & 0.555 & Absent & $99 \pm 8.8$ & 77 & 71 & & 0.02 & 0.786 & Absent \\
\hline & $24 \mathrm{~B}$ & $87 \pm 2.7$ & 93 & 86 & & 0.26 & 0.015 & Absent & $88 \pm 7.5$ & 86 & 79 & & 0.24 & 0.011 & Absent & $100 \pm 2.6$ & 77 & 71 & & 0.00 & 0.268 & Absent \\
\hline & $31 \mathrm{~B}$ & $23 \pm 3.7$ & 93 & 86 & 48 & 2.08 & $<\mathbf{0 . 0 0 1}$ & Very high & $100 \pm 1.2$ & 86 & 79 & & 0.00 & 0.735 & Absent & $100 \pm 5.6$ & 77 & 71 & & 0.00 & 0.852 & Absent \\
\hline & 33B & $72 \pm 2.2$ & 93 & 86 & & 0.56 & $<0.001$ & Medium & $95 \pm 7.6$ & 86 & 79 & & 0.1 & 0.26 & Absent & $80 \pm 6.8$ & 77 & 71 & & 0.41 & $<0.001$ & Absent \\
\hline \multirow{10}{*}{$\begin{array}{l}\text { P. lividus embryo } \\
\text { toxicity test }\end{array}$} & $2 \mathrm{~B}$ & $21 \pm 9.1$ & 83 & 74 & 82 & 1.22 & $<0.001$ & Medium & $0 \pm 0.0$ & 74 & 66 & 39 & 2.56 & $<0.001$ & High & $100 \pm 3.1$ & 75 & 67 & & 0.00 & 0.349 & Absent \\
\hline & $8 \mathrm{~B}$ & $85 \pm 4.2$ & 83 & 74 & & 0.30 & $<0.001$ & Absent & $0 \pm 0.0$ & 83 & 74 & 44 & 2.27 & $<0.001$ & High & $0 \pm 0.0$ & 75 & 67 & 72 & 1.39 & $<0.001$ & Medium \\
\hline & $11 \mathrm{~B}$ & $75 \pm 4.9$ & 83 & 74 & & 0.50 & $<0.001$ & Absent & $92 \pm 6.4$ & 71 & 63 & & 0.16 & 0.021 & Absent & $100 \pm 8.3$ & 75 & 67 & & 0.00 & 0.525 & Absent \\
\hline & $14 \mathrm{~B}$ & $86 \pm 7.6$ & 83 & 74 & & 0.28 & $<\mathbf{0 . 0 0 1}$ & Absent & $93 \pm 5.7$ & 71 & 63 & & 0.06 & 0.011 & Absent & $3 \pm 2.3$ & 75 & 67 & 47 & 2.13 & $<\mathbf{0 . 0 0 1}$ & High \\
\hline & $16 \mathrm{~B}$ & $0 \pm 0.0$ & 83 & 74 & 38 & 2.63 & $<0.001$ & High & $0 \pm 0.0$ & 71 & 63 & 46 & 2.17 & $<0.001$ & High & $0 \pm 0.0$ & 75 & 67 & 27 & 3.70 & $<0.001$ & High \\
\hline & $19 \mathrm{~B}$ & $80 \pm 7.6$ & 83 & 74 & & 0.40 & $<0.001$ & Absent & $19 \pm 11.2$ & 83 & 74 & 80 & 1.25 & $<0.001$ & Medium & $76 \pm 0.0$ & 75 & 67 & & 0.48 & $<0.001$ & Absent \\
\hline & $22 \mathrm{~B}$ & $98 \pm 4.8$ & 83 & 74 & & 0.04 & 0.455 & Absent & $79 \pm 2.1$ & 83 & 74 & & 0.42 & $<0.001$ & Absent & $89 \pm 8.6$ & 75 & 67 & & 0.22 & 0.003 & Absent \\
\hline & $24 \mathrm{~B}$ & $31 \pm 6.0$ & 83 & 74 & 91 & 1.11 & $<0.001$ & Medium & $90 \pm 1.8$ & 83 & 74 & & 0.20 & $<0.001$ & Absent & $100 \pm 6.8$ & 75 & 67 & & 0.00 & 0.237 & Absent \\
\hline & $31 \mathrm{~B}$ & $57 \pm 8.6$ & 83 & 74 & & 0.86 & $<0.001$ & Low & $58 \pm 5.1$ & 83 & 74 & & 0.84 & $<0.001$ & Low & $76 \pm 4.3$ & 75 & 67 & & 0.48 & $<0.001$ & Absent \\
\hline & 33B & $0 \pm 0.0$ & 83 & 74 & 55 & 1.82 & $<0.001$ & Medium & $0 \pm 0.0$ & 83 & 74 & 45 & 2.22 & $<0.001$ & High & $0 \pm 0.0$ & 75 & 67 & 38 & 2.63 & $<0.001$ & High \\
\hline \multirow{10}{*}{$\begin{array}{l}\text { C. gigas embryo } \\
\text { toxicity test }\end{array}$} & $2 \mathrm{~B}$ & $100 \pm 5.1$ & 80 & 74 & & 0.00 & 0.759 & Absent & $0 \pm 0.0$ & 84 & 78 & 66 & 1.52 & $<0.001$ & Medium & $91 \pm 4.3$ & 84 & 78 & & 0.18 & $<0.001$ & Absent \\
\hline & $8 \mathrm{~B}$ & $97 \pm 9.8$ & 80 & 74 & & 0.06 & 0.321 & Absent & $62 \pm 4.8$ & 84 & 78 & & 0.76 & $<0.001$ & Low & $75 \pm 7.6$ & 84 & 78 & & 0.50 & $<0.001$ & Low \\
\hline & $11 \mathrm{~B}$ & $88 \pm 4.3$ & 80 & 74 & & 0.24 & 0.001 & Absent & $97 \pm 1.8$ & 84 & 78 & & 0.06 & 0.031 & Absent & $71 \pm 4.3$ & 84 & 78 & & 0.58 & $<0.001$ & Low \\
\hline & $14 \mathrm{~B}$ & $82 \pm 1.3$ & 80 & 74 & & 0.36 & $<0.001$ & Absent & $100 \pm 4.3$ & 84 & 78 & & 0.00 & 0.414 & Absent & $77 \pm 2.4$ & 84 & 78 & & 0.46 & $<0.001$ & Low \\
\hline & $16 \mathrm{~B}$ & $58 \pm 8.0$ & 80 & 74 & & 0.84 & $<0.001$ & Low & $83 \pm 9.2$ & 84 & 78 & & 0.34 & $<0.001$ & Absent & $0 \pm 0.0$ & 84 & 78 & 39 & 2.56 & $<0.001$ & High \\
\hline & 19B & $100 \pm 2.6$ & 80 & 74 & & 0.00 & 0.041 & Absent & $82 \pm 2.7$ & 84 & 78 & & 0.36 & $<0.001$ & Absent & $79 \pm 1.2$ & 84 & 78 & & 0.42 & $<\mathbf{0 . 0 0 1}$ & Absent \\
\hline & $22 \mathrm{~B}$ & $100 \pm 2.6$ & 80 & 74 & & 0.00 & 0.863 & Absent & $100 \pm 1.8$ & 84 & 78 & & 0.00 & 0.231 & Absent & $94 \pm 1.8$ & 84 & 78 & & 0.12 & $<\mathbf{0 . 0 0 1}$ & Absent \\
\hline & $24 \mathrm{~B}$ & $92 \pm 2.6$ & 80 & 74 & & 0.16 & 0.016 & Absent & $100 \pm 0.0$ & 84 & 78 & & 0.00 & 0.722 & Absent & $87 \pm 3.6$ & 84 & 78 & & 0.26 & $<\mathbf{0 . 0 0 1}$ & Absent \\
\hline & $31 \mathrm{~B}$ & $91 \pm 2.6$ & 80 & 74 & & 0.18 & 0.010 & Absent & $92 \pm 3.6$ & 84 & 78 & & 0.16 & $<0.001$ & Absent & $95 \pm 1.4$ & 84 & 78 & & 0.10 & 0.002 & Absent \\
\hline & 33В & $27 \pm 3.6$ & 80 & 74 & 80 & 1.25 & $<0.001$ & Medium & $32 \pm 1.8$ & 84 & 78 & 88 & 1.14 & $<0.001$ & Medium & $0 \pm 0.0$ & 84 & 78 & 47 & 2.13 & $<0.001$ & High \\
\hline
\end{tabular}

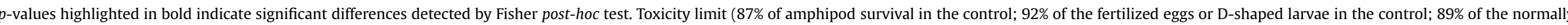
developed plutei in the control) is the value below which the percentage success (S\%) in the sample is significantly different from control, according to minimum significant difference (MSD) criterion. 
the experimental period, resulting in a mean $\mathrm{EC}_{50}$ of $54 \pm 13 \mu \mathrm{g} / \mathrm{L}$ of $\mathrm{Cu}$; all $\mathrm{EC}_{50}$ values fell within the interval of the intra-laboratory control chart (24-75 $\mu \mathrm{g} / \mathrm{L}$ of $\mathrm{Cu}, n=31$ ) according to Volpi Ghirardini et al. (2005c). Mean percentage of fertilized eggs in the control water was $84 \pm 6 \%(n=26)$.

The results of the sperm cell tests are summarized in Table 4. Toxicity was observed only in three samples from the spring campaign that is the samples located in the industrial area $(8 \mathrm{~B}$ and $33 \mathrm{~B}$ ) and near the city of Venice (31B). In 31B, the effects were particularly marked, with an $\mathrm{EC}_{50}$ equal to $48 \%$ (high toxicity). No data below the toxicity limits were observed in autumn and winter campaigns, despite some statistical differences were highlighted by ANOVA.

The Kruskal-Wallis analysis showed a significant seasonal toxicity trend: the elutriates obtained in spring resulted significantly more toxic $(p<0.001)$ than those obtained from autumn and winter samples. The difference between sampling campaigns was most probably due to the significant effects measured in sites $8 \mathrm{~B}, 31 \mathrm{~B}$ and $33 \mathrm{~B}$ during the spring campaign and not confirmed during the following surveys. Despite this seasonal difference, no spatial classification of the effects was evidenced $(p=0.46)$.

\subsubsection{Embryotoxicity test with the sea urchin P. lividus}

The mean $\mathrm{EC}_{50}$ value found with the reference toxicant during the experimental period was $57 \pm 12 \mu \mathrm{g} / \mathrm{L}$ of $\mathrm{Cu}(n=4)$, with single data ranging from $44 \mathrm{up}$ to $73 \mu \mathrm{g} / \mathrm{L}$ of $\mathrm{Cu}$; all data fell within the limits of the intra-laboratory control chart $(40-80 \mu \mathrm{g} / \mathrm{L}$ of $\mathrm{Cu}$, $n=17$ ) according to Volpi Ghirardini et al. (2005c). The mean value of normally developed embryos in negative controls was $82 \pm 4 \%$ $(n=14)$.

Only elutriates from sites $11 \mathrm{~B}$ and $22 \mathrm{~B}$ were not toxic towards the sea urchin embryos in all campaigns; for all the other sites, at least one sample resulted to affect sea urchin development in one of the campaigns (Table 4). In the spring campaign, five samples resulted toxic: the highest effect was observed in the elutriate extracted from 16B sediment (high toxicity), while samples 2B, $24 \mathrm{~B}$ and $33 \mathrm{~B}$ showed medium toxicity levels. Low effects were found in the elutriate extracted from sediments collected close to Venice city centre (31B). In the autumn campaign six samples resulted as toxic: the highest inhibition of the larval development was measured in the industrial area ( $8 \mathrm{~B}$ and $33 \mathrm{~B}$ ) and in the mudflats (2B and $16 \mathrm{~B}$ ). Less marked effects were found in $19 \mathrm{~B}$ (medium toxicity) and 31B (low toxicity). In winter only four samples resulted as toxic and two main groups were identified. A first grouping was characterized by absent or negligible toxicity and included the sediments collected in the central basin of the Lagoon (11B and 31B), both the mudflats of the northern Lagoon (2B and 22B) and two of the three sites located near the sea-inlets (19B and 24B); the second group was characterized by high or very high toxicity and included samples $14 \mathrm{~B}, 16 \mathrm{~B}$ and 33B. As in the previous campaigns, sample $16 \mathrm{~B}$ was the sample eliciting the highest toxic effect $\left(\mathrm{EC}_{50}=27 \%\right)$.

ANOVA highlighted a strong difference among sampling sites of the toxicity toward sea urchin larval development $(p<0.001)$, while no significant difference was observed among the sampling campaigns $(p=0.29)$. The sites $33 \mathrm{~B}$ and $16 \mathrm{~B}$ were the most toxic toward the sea urchin embryos and formed a group significantly different from all the other sites $(p<0.01)$; the lowest effect (absent toxicity) was measured in sites $11 \mathrm{~B}$ and 22B. The use of a set of $a$ priori contrasts showed that the inhibition of larval development measured in the industrial area $(8 \mathrm{~B}, 33 \mathrm{~B})$ was significantly higher than those detected in the northern basin (2B, 22B), in the central basin $(11 \mathrm{~B}, 31 \mathrm{~B})$ and in the areas closest to the sea inlets (14B, 19B, 24B) ( $p<0.001$ for all the contrasts). The mudflat Valle Millecampi (16B) was the site eliciting the highest inhibition of larval development in respect to the other sites.

\subsubsection{Embryotoxicity test with the oyster $C$. gigas}

Four tests were carried out with the reference toxicant $(\mathrm{Cu})$, resulting in a mean $\mathrm{EC}_{50}$ of $12 \pm 4 \mu \mathrm{g} / \mathrm{L}$. All the $\mathrm{EC}_{50}$ values were within the control chart limits (Libralato et al., 2009, 2010). The percentage of normally developed D-shape larvae in the wateronly controls was always $>70 \%$ (mean value of $82 \pm 5 \%, n=27$ ).

Toxicity results with oyster larvae are reported in Table 4 . In the spring campaign, toxic effects were measured only in the industrial canal 33B (medium toxicity) and in the confined mudflat 16B (low toxicity). In all other samples, no toxicity was highlighted, even if the analysis of variance detected significant deviations from control conditions in the samples of the central basin and the samples collected near the sea-inlets.

In autumn, toxicity was found only in site $2 \mathrm{~B}$ and in the samples from the industrial area ( $8 \mathrm{~B}$ and $33 \mathrm{~B})$. The observed effects ranged from low to medium. In all other elutriates, the percentage of normally developed embryos was always higher that the toxicity threshold.

The effects on larval development were significantly higher in winter, since five samples were classified as toxic. The highest effects were measured in 33B and $16 \mathrm{~B}$ (high toxicity), while $8 \mathrm{~B}$, $11 \mathrm{~B}$ and $14 \mathrm{~B}$ were characterized by low toxicity.

As the embryotoxicity test with the sea urchins, the results of the bioassay with the oysters showed no significant variation through the experimental period $(p=0.08)$, but a clear spatial difference $(p<0.001)$. Elutriates obtained from the sediment of the industrial canal (33B) were the most toxic, followed by the group of sites $2 \mathrm{~B}, 8 \mathrm{~B}$ and $16 \mathrm{~B}$. The lowest effects were measured in the sites of the central basin $(11 \mathrm{~B}, 31 \mathrm{~B})$ and near the sea inlets. The spatial trend evidenced by the a priori contrast was consistent with the gradient observed with the sea urchins: the toxicity in the industrial area was significantly higher than the effects measured in the other basins and near the sea inlets $(p<0.001)$, but it is equal to the toxicity detected in site $16 \mathrm{~B}(p=0.88)$

\subsection{Multivariate analysis}

The factor analysis was performed on 22 variables: $\mathrm{As}, \mathrm{Cd}, \mathrm{Cr}$, $\mathrm{Cu}, \mathrm{Hg}, \mathrm{Ni}, \mathrm{Pb}, \mathrm{Zn}, \mathrm{AVS}, \mathrm{PAHs}, \mathrm{PCBs}, \mathrm{HC}>12, \mathrm{HCB}, \mathrm{TOC}$, percentage of sand, silt and clay, total ammonia, amphipod test (CV-M), sperm cell test (PL-SP), embryotoxicity with sea urchins (PL-EM) and embryotoxicity with oysters (CG-EM). $\mathrm{HC}<12$ and OCP were $a$ priori discarded since they were always below the detection limit. The 22 original variables can be represented by five new variables (factors) explaining $84.5 \%$ of the variance of the original data. The rotated factor loading is reported in Table 5; these values are coefficients relating the original variables with the new factors provided by the factor analysis. Only variables with loading greater than 0.4 were considered as those associated with the factors; according to DelValls et al. (1999), loadings greater than 0.4 correspond to an associated explained variance over 30\% and approximates Comrey's (1973) cut-off of 0.55 for a good association between an original variable and a component.

The first factor (factor 1 ) accounts for the $48.1 \%$ of the variance and combines sediment concentrations of $\mathrm{As}, \mathrm{Cd}, \mathrm{Cu}, \mathrm{Hg}, \mathrm{Pb}, \mathrm{Zn}$, PAHs, PCBs and HCB with ammonia concentration in the elutriates, clay content and the effects measured on the larval development of the oysters. This factor represents typical phenomena of environmental degradation due to contamination from industrial sources ( $\mathrm{Cd}, \mathrm{Cu}, \mathrm{Hg}, \mathrm{Zn}, \mathrm{PCBs}, \mathrm{HCB}$ and at least partially ammonia) and boat traffic ( $\mathrm{Pb}$ and PAHs).

The second factor (factor 2 ) accounts for $12.5 \%$ of the variance and represents a combination of sediment concentration of $\mathrm{As}, \mathrm{Cr}$ and Ni, TOC content, percentage of clay, effect on sea urchins development. This factor thus associates physico-chemical conditions common in the landward areas of the Lagoon (far from the 
Table 5

Summary of rotated factor scores. In bold are highlighted the scores higher than 0.4 or lower than -0.4 . The ecotoxicological data are reported in last 4 rows (CV$\mathrm{M}=C$. volutator; $\mathrm{PL}-\mathrm{SP}=P$. lividus sperm cell test; $\mathrm{PL}-\mathrm{EM}=P$. lividus embryo toxicity; $\mathrm{CG}-\mathrm{EM}=C$. gigas embryo toxicity).

\begin{tabular}{|c|c|c|c|c|c|}
\hline & Factor 1 & Factor 2 & Factor 3 & Factor 4 & Factor 5 \\
\hline TOC & -0.0122 & 0.8757 & -0.0546 & 0.0151 & 0.2749 \\
\hline Sand & -0.2565 & -0.2185 & -0.9061 & -0.0548 & -0.0427 \\
\hline Silt & 0.0608 & -0.0872 & 0.9420 & -0.0608 & 0.1346 \\
\hline Clay & 0.4015 & 0.4770 & 0.7123 & 0.1575 & -0.0539 \\
\hline $\mathrm{NH}_{3}$ & 0.4702 & 0.2596 & 0.3866 & 0.6080 & 0.0243 \\
\hline AVS & 0.0303 & 0.0619 & 0.7248 & 0.1292 & -0.2505 \\
\hline As & 0.7008 & 0.5393 & 0.1367 & 0.2571 & -0.0342 \\
\hline $\mathrm{Cd}$ & 0.9278 & 0.1751 & -0.0009 & -0.0905 & -0.0311 \\
\hline $\mathrm{Cr}$ & 0.2958 & 0.8488 & 0.1397 & 0.1257 & -0.1849 \\
\hline $\mathrm{Cu}$ & 0.7921 & 0.1618 & 0.2775 & -0.0514 & 0.1673 \\
\hline $\mathrm{Hg}$ & 0.8334 & -0.0131 & 0.4312 & 0.1255 & 0.1214 \\
\hline $\mathrm{Ni}$ & 0.2882 & 0.8728 & 0.2141 & 0.0195 & -0.1833 \\
\hline $\mathrm{Pb}$ & 0.8264 & 0.3743 & 0.3096 & 0.0144 & 0.0798 \\
\hline $\mathrm{Zn}$ & 0.9195 & 0.2918 & 0.0840 & -0.0040 & 0.0958 \\
\hline Total PAHs & 0.7944 & -0.0215 & 0.1352 & 0.1912 & 0.4414 \\
\hline Total PCBs & 0.9449 & 0.0737 & 0.1010 & 0.2104 & 0.0467 \\
\hline HCB & 0.9427 & 0.1491 & 0.0324 & 0.1863 & -0.0350 \\
\hline SVOCs & 0.2876 & 0.1368 & 0.1010 & 0.2444 & 0.7353 \\
\hline PL-EM & 0.2244 & 0.6778 & 0.0753 & 0.5692 & 0.2193 \\
\hline PL-SP & 0.0874 & -0.1692 & -0.0258 & -0.2137 & 0.7147 \\
\hline CG-EM & 0.4343 & 0.3837 & 0.0886 & 0.7164 & 0.0497 \\
\hline CV-M & -0.3095 & -0.2464 & -0.1786 & 0.6317 & -0.1164 \\
\hline
\end{tabular}

sea inlets) with effects on larval development of the sea urchins; high TOC content, Cr, Ni and also As (Degetto et al., 2003) are naturally occurring sediment features in these areas. The third factor (11.0\% of the variance) associates $\mathrm{Hg}$ sediment concentrations, AVS and fine grained sediments; it represents typical geochemical characteristics of sediments of the confined mudflats, far from point sources of contamination, associated with absence of significant toxicity. The fourth factor (factor 4) accounts for the $6.7 \%$ of the variance of the original dataset and combines ammonia concentrations in the elutriate with toxic effects, especially towards sea urchins and oysters. The fifth factor (factor 5) binds $\mathrm{HC}>12$ and PAHs concentrations with sperm cell test results and accounts only for the $6.2 \%$ of the variance.

The graphical representation of the estimated factor scores (Fig. 2) helps establish a relationship between the five factors and the environmental conditions at each of the studied stations. Moreover, graphics help to confirm the description of the factor reported above (Riba et al., 2004).

Positive values for factor 1 were found only for the samples of the industrial area ( $8 \mathrm{~B}$ and $33 \mathrm{~B}$ ) that were confirmed as the most contaminated and toxic toward oyster embryos. All the other samples were characterized by negative values of factor 1 (except sample $31 \mathrm{~B}$, autumn campaign); as a consequence it can be assumed that they did not show contamination levels nor toxicity that could be related to industrial pollution. The positive factor score found in sample 31B (autumn campaign) evidences the occurrence of significant contamination in this area too, especially about PAHs (Table 3); nevertheless, in contrast with the sites of the industrial area (8B and 33B), site 31B did not show toxicity toward oyster and this probably influenced score estimation.

About factor 2, positive score values were found for samples 2B, $8 \mathrm{~B}, 16 \mathrm{~B}$ and $33 \mathrm{~B}$ (only spring), but only in sample 16B (both spring and autumn) and sample 8B (autumn) it became significant; in these samples it cannot be excluded that embryotoxicity test results could have been affected by $\mathrm{As}, \mathrm{Cr}$, $\mathrm{Ni}$ and organic substances (especially humic substances, free and combined amino acids and related compounds) released by the sediments.

The sites located near the sea-inlets (14B, 19B and 24B) showed negative prevalence for factor 3 , whilst the higher positive scores were found in the fine grained, shallow water mudflats of the northern basin (2B and 22B), were AVS concentrations are high throughout the year and $\mathrm{Hg}$ concentrations are intermediate between the values of the sea-inlets and those recorded in the industrial area.

Samples 2B, 19B and 33B showed a clear positive prevalence for factor 4 , but only during autumn campaign; the toxic effects observed in $2 \mathrm{~B}$ and $33 \mathrm{~B}$ were most probably due to ammonia concentrations, whilst in 19B ammonia concentration was too low to explain the adverse effects detected on sea urchins embryos thus the toxicity is probably due to the co-occurrence of ammonia and other contaminants. Positive scores for factor 4 were also found for samples $8 \mathrm{~B}$ and $11 \mathrm{~B}$ in the autumn campaign and for sample $14 \mathrm{~B}$ in the spring campaign; nevertheless, only in sample $8 \mathrm{~B}$ a possible role of ammonia to the overall toxicity could be expected. In fact, no adverse effect toward any of the used tests was measured in $11 \mathrm{~B}$ and 14B. About 8B, factor 4 has a lower importance compared to the other factors, so the contribute of ammonia to the toxicity is secondary with respect to the effects due to industrial contamination (factor 1 ) and to the variables characterizing factor 2 (As, $\mathrm{Cr}, \mathrm{Ni}$, and $\mathrm{TOC}$ ).

About factor 5, significant positive values were found in samples $8 \mathrm{~B}$ (autumn) and 31B (spring); this factor became particularly interesting since it provide a reasonable explanation of the effects toward sperm-cells observed in sample 31B during spring campaign. Regarding sample $8 \mathrm{~B}$, since no effects toward the sperm cells was observed, the positive score was probably induced by the concentrations of PAHs and $\mathrm{HC}>12$, that were among the highest measured during the entire study (Table 3 ).

\section{Discussion}

On the basis of the mPELq data and the number of chemicals exceeding PEL, it was possible to identify three main groupings of samples that are consistent with the macro-areas categorized by the embryotoxicity tests with sea urchins and oysters. The samples collected near the sea inlets were characterized by the lowest mPELq values (0-0.20) and none of the chemical exceeded PEL values; the samples of the open lagoon showed mPELq values ranging from 0.20 up to 0.38 and only $\mathrm{Hg}$ concentrations were above PELs (2B, 11B, 22B and 31B), whilst the samples of the industrial area ( $8 \mathrm{~B}$ and $33 \mathrm{~B}$ ) were characterized by the higher mPELq values $(0.60-0.88)$ and concentrations of $\mathrm{Hg}$ and $\mathrm{Zn}$ above PEL. The only exception to this trend is site $16 \mathrm{~B}$ whose toxicity (for the reasons already outlined) is comparable to the one of the sites in the industrial area despite its lower level of contamination.

Sediment chemistry also confirmed that the metals are the main class of contaminants of potential concern; in several samples were exceeded the Threshold Effect Level (TEL) values for As, $\mathrm{Cd}, \mathrm{Cu}, \mathrm{Ni}$ and $\mathrm{Pb}$ and the PEL values for $\mathrm{Hg}$ and $\mathrm{Zn}$, while organic micro-contaminants were generally below the effective and threshold concentrations reported in the literature (MacDonald et al., 1996). Nevertheless, the bioavailability of the divalent metals is strongly limited by the occurrence of a surplus of AVS and Organic Carbon (Table 3), so that their potential toxicity towards the biota can be considered negligible.

The low concentrations of organic micro-pollutants and the occurrence of ligands in the sediments that limit metals bioavailability are key factors for interpreting toxicity test results, especially about the amphipod test. In fact, $C$. volutator mortality test was clearly the less discriminating assay, since it was unable to detect significant effects despite clear differences up to 1-2 order of magnitude in sediment concentration for some contaminants (Table 3). Nevertheless, the comparison of the chemistry data with the available literature concerning $C$. volutator suggested that 
एय] factor 1
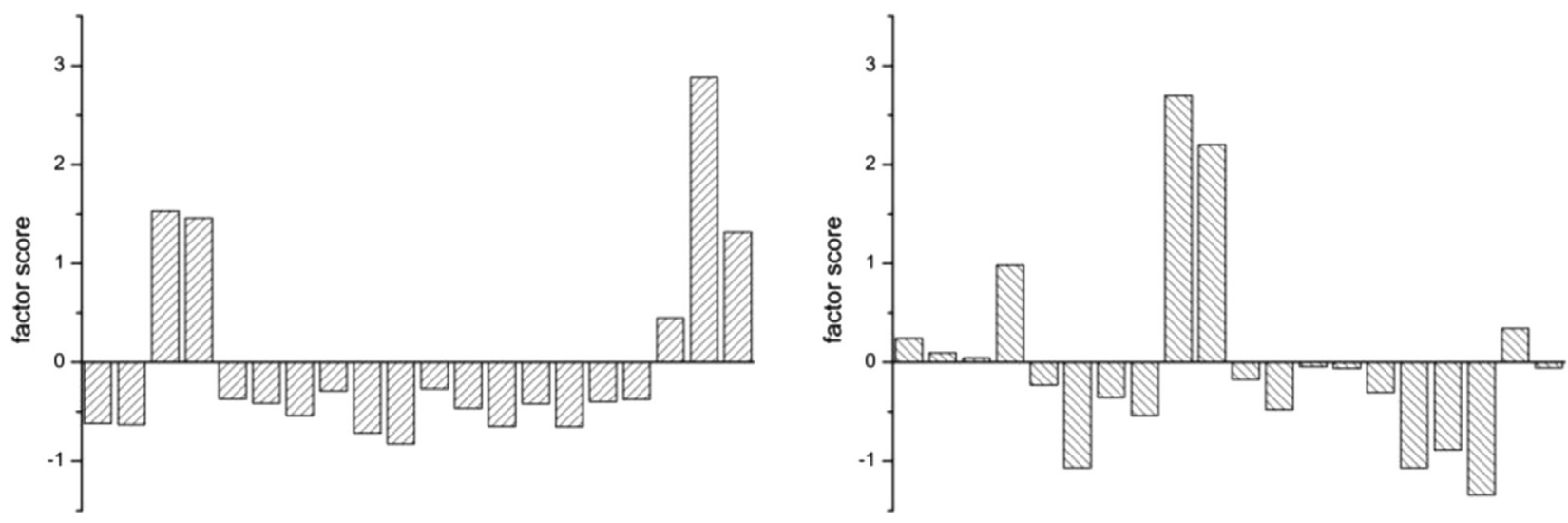

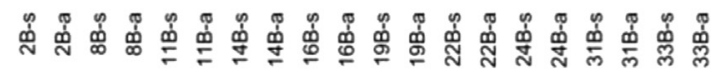

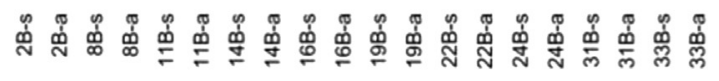

factor 3
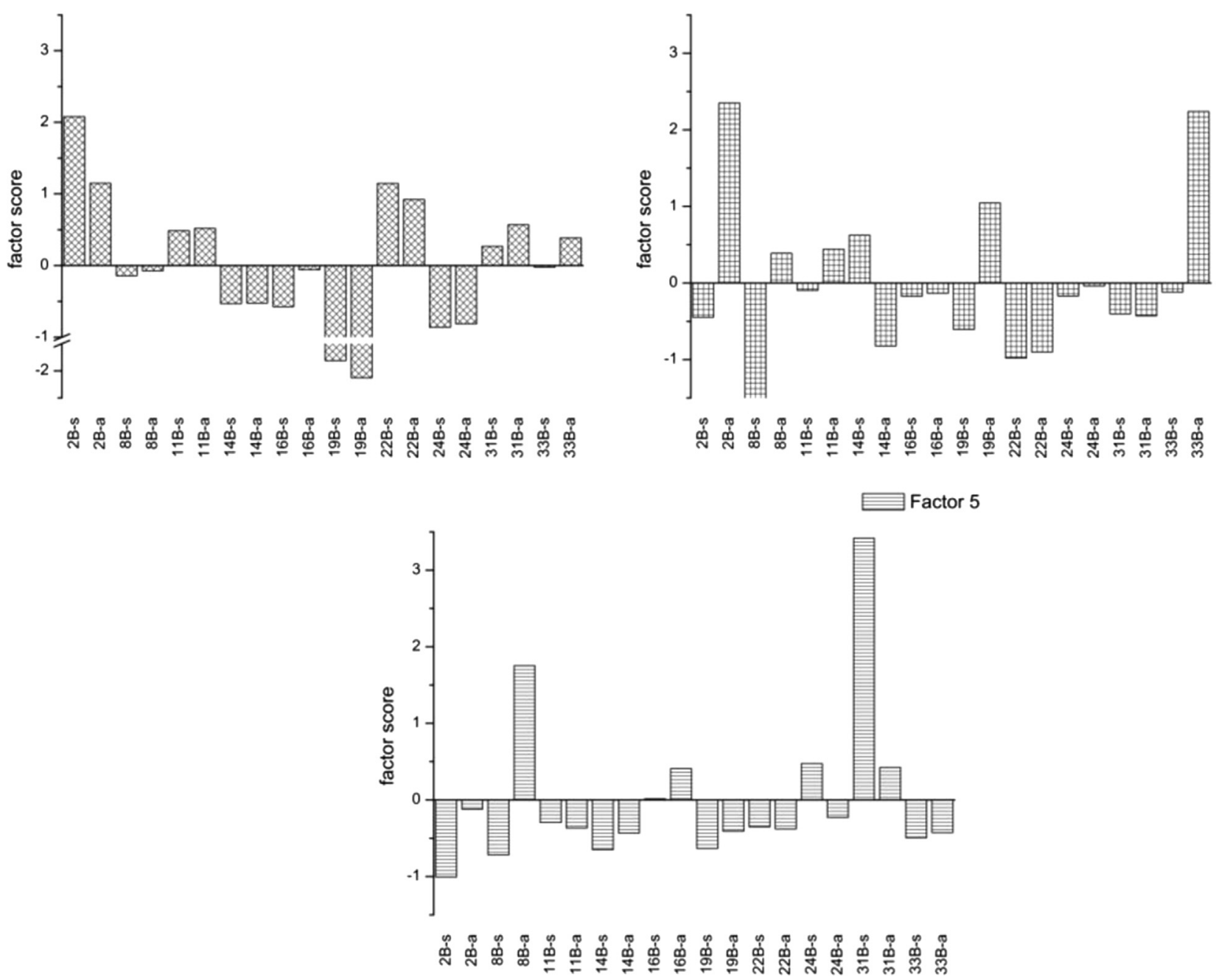

Fig. 2. Estimated factor scores. $-\mathrm{a}$ and $-\mathrm{s}$ indicate autumn and spring campaign, respectively. The bar plots show the relative score for the 5 identified factors. For a given sample within each factor, higher positive scores highlight stronger relationships among the combined variables. Negative value of the factor score for a given sample evidences the lack of correlations among the parameters. Factor 1 relates sediment concentration of $\mathrm{As}, \mathrm{Cd}, \mathrm{Cu}, \mathrm{Hg}, \mathrm{Pb}, \mathrm{Zn}, \mathrm{PAHs}, \mathrm{PCBs}$ and $\mathrm{HCB}$ with ammonia in the elutriates, clay content and oyster embryo toxicity. Factor 2 relates sediment concentration of As, Cr, Ni, TOC, clay content and sea urchin embryo toxicity. Factor 3 associates sediment concentration of $\mathrm{Hg}$, AVS and fine sediments. Factor 4 combines ammonia in the elutriate with toxic effects toward sea urchin and oysters. Factor 5 associates $\mathrm{HC}>12$, PAHs and sperm cell test. 
sediment contamination in the investigated sites, especially in regard to hydrocarbons and PAHs (Table 3), was too low to induce mortality of adult amphipods. Grant and Briggs (2002) observed significant mortality of $C$. volutator in sediments located near oil platforms where total hydrocarbons concentration exceeded $153 \mathrm{mg} / \mathrm{kg} \mathrm{dw}$, and Tay et al. (1992) found mortality only in highly contaminated harbours where PAHs were detected at concentrations $>435 \mathrm{mg} / \mathrm{kg} \mathrm{dw}$. About other contaminants, laboratory studies performed on pure substances showed that the amphipods of the genus Corophium are generally more tolerant to pure chemicals than other species of amphipods (Bat and Raffaelli, 1998; Picone et al., 2008; Prato et al., 2015). In any case, it should be stressed that the $10 \mathrm{~d}$ lethality test with amphipods is recognized as a reliable tool only for the identification of hot-spot of contamination, but its ability to distinguish among sediments characterized by low to moderate contamination (as those investigated in this study) is uncertain, independently from the species used as indicator (USEPA, 2001). Amphipod chronic tests, possibly involving full life-cycle of autochthonous species could be more effective for evidencing possible impacts on populations due to low-moderate contamination levels (Redmond et al. 1997, Costa et al. 2005, Scarlett et al. 2007, van den Heuvel-Greve et al., 2007).

About the sperm-cell test, even if it was successfully used in the past for characterizing the toxicity of Venice Lagoon sediments, especially for elutriates from industrial channels (Volpi Ghirardini et al., 2005b; Arizzi Novelli et al., 2006) it showed to be not enough sensitive to highlight effects in elutriate extracted from surface sediments characterized by low or moderate contamination, as those investigated in this study. Significant toxicity was observed only in three elutriate samples of the spring campaign, with medium toxicity found in the industrial area (8B and 33B) and very high effects measured close to the city of Venice (31B). For sample 31B, multivariate analysis suggested a possible relation with $\mathrm{PAHs}$ and $\mathrm{HC}>12$ sediment concentration. Other studies evidenced that the sperm cell test with the sea urchin showed higher sensitivity and discriminating ability when applied to porewaters of lagoon sediments (Losso et al., 2009) and is less prone to ammonia masking effects as other tests, even if it less sensitive than embryos test to a wide range of contaminants (Losso et al. 2007b).

In contrast to acute tests, the two embryotoxicity tests showed a high discriminating ability, evidencing significant effects in samples from the industrial area, and negligible or low effects in the sites located near the sea-inlets (in particular 19B and 24B) and in the mudflats of the Northern basin (22B), a priori chosen as potential reference sites.

Factor analysis confirmed that both tests were affected by the occurrence of high ammonia concentrations in the elutriates, especially for sites $2 \mathrm{~B}$ and $33 \mathrm{~B}$; for the remaining sites it was also evidenced that oyster responses in the industrial area were clearly linked with industrial contamination, while sea urchin responses could have been affected by $\mathrm{As}, \mathrm{Cr}$, Ni and organic compounds released by organic matter in sites $8 \mathrm{~B}$ and $16 \mathrm{~B}$.

The results between sea urchin and oyster embryos were correlated (Spearman $R=0.67, p<0.001$ ) despite some different responses obtained especially in the mudflats $2 \mathrm{~B}$ and $16 \mathrm{~B}$. These correlations confirmed previous results (Losso et al., 2007a).

About site 16B-Valle Millecampi, the high toxicity that was measured (despite the low level of contamination) and the different responses provided by sea urchins and oysters can be explained by considering ammonia contribution to the overall toxicity (factor 2) and the observed relationship among sea urchin larval development and sediment concentration of $\mathrm{Cr}$, As and TOC (factor 3 ). The toxicity towards oysters was classified as high only in the winter campaign (Table 4), while the larval development of the sea urchin was significantly inhibited in all the three campaigns (Table 4). Since its concentrations in 16B reached critical levels only during winter (Table 2), ammonia can certainly be regarded as the main toxicant of concern for oyster embryos at this station, while the effects measured towards sea urchins were probably due to the co-occurrence of ammonia (especially in winter) and other factors, as those highlighted by factor analysis. The environmental conditions in site $16 \mathrm{~B}$ are completely different as compared with all the other investigated areas: high water renewal time, bed of oysters on the bottom, presence of peat and vegetal debris in the sediment. In this context, it cannot be excluded that the partially contrasting results could be due to the occurrence of non-contaminant factors, as high concentration of dissolved OC, affecting embryo-larval development of the sea urchin, but not distressing the oysters, which are well adapted for living in brackish ecosystems.

In any case, the data suggested that the role of ammonia as potential causal factor deserves carefully evaluation, both in the industrial area $(8 \mathrm{~B}, 33 \mathrm{~B})$ and in the mudflats $(2 \mathrm{~B}, 16 \mathrm{~B})$, as highlighted the significant and positive correlations observed with the embryo toxicity tests with both sea urchins and oysters (Spearman $R=0.50, p<0.001$ for sea urchins; $R=0.67, p<0.0001$ for oysters) as well as the occurrence of concentrations higher than the toxicity thresholds reported in literature for sea urchins and oysters (Arizzi Novelli et al. 2003; Losso et al., 2007b).

Minor differences between the two embryo toxicity tests were observed both in site $14 \mathrm{~B}$ and $2 \mathrm{~B}$, where the sea urchins highlighted transient and unexpected seasonal changes of the toxicity, in contrasts with oyster data. Since sediment chemistry and ammonia concentrations did not show any significant temporal variation of the contamination levels that could justify these peaks of effect towards the sea urchins, these results could be interpreted as an outcome of the higher consistency and reliability provided by the cultured specimens of oysters with respect to the wild population of sea urchins in the sediment quality assessment.

\section{Conclusion}

This study reports toxicity data on elutriates and sediments of the Venice lagoon, tested with a battery of 4 bioassays using amphipods and early life stages of sea urchin and oysters. The results were compared with chemistry data and discussed to evaluate the reliability of the methods for their use in an effective multi-species and multi-endpoints battery of ecotoxicity tests for Venice lagoon sediment. Discriminating ability of the tests, possible occurrence of spatial and temporal toxicity gradient and correlation with chemistry data were also discussed.

Sediment chemistry provided evidence that contamination levels in the investigated sites resulted to be low to moderate and this was most probably the main factor affecting acute test results, especially amphipod lethality test.

The multi-species set of bioassays allowed the identification of a gradient of effect among the investigated sites, with decreasing toxicity from the industrial area toward the sea-inlets; nevertheless, only the two embryotoxicity test were able to discriminate among the sites characterized by different levels of contamination, whilst absence of toxicity was generally observed with the acute tests (amphipod mortality test and sperm cell test with the sea urchins).

The major toxic effects were measured in the sites characterized by higher anthropogenic pressure, the industrial area, and in confined mudflats; larval development impairments were linked to anthropogenic sources of contamination in the industrial area and to ammonia both in the industrial area and in the mudflats. A confined site showed an anomalous high toxicity toward sea urchin embryos that could be linked to peculiar environmental 
condition both about sediment geochemistry as well as hydrodynamics. Despite a clear spatial gradient, no significant temporal variation of the toxicity was observed within the experimental period.

The evidences concerning the contamination levels and the general absence of acute toxicity suggest that most of the sediments of the Venice Lagoon does not represent a risk to the biota, at least in the short term. Thus, efforts should be focused on differentiating the monitoring strategies among the most impacted sites, where a surveillance system based on acute and sub-chronic tests is needed, and the other areas of the lagoon, located far from point and clearly identifiable sources of contamination, where the evaluation of medium to long term effects is of greatest ecological interest for the sustainable management of the environment and its services.

This new perspective imply the necessary implementation of the here proposed set of bioassays with test methods developed for the assessment of long-term effects, especially about the sediment test, the more relevant laboratory procedure able to "simulate" in situ exposure. Long-term effects are better evaluated by using sub-lethal endpoints of greater ecological relevance than survival, such as growth, attainment of maturation and reproduction; as a consequence, the monitoring of the less impacted areas should be preferably performed by replacing the acute sediment test with amphipods with a chronic test, possibly involving full life-cycle of autochthonous species.

The monitoring of the acute toxicity could be improved too; acute effects could be better addressed by introducing in the set of bioassays at least a pore-water test (the sperm cell with sea urchin as an example), since pore-waters are a key exposure route for sediment-associated organisms, in particular about water-soluble chemicals.

The above-mentioned amendments to the set of bioassays will certainly provide more reliability and consistency to the characterization of the (possible) toxic effects due to the sediment contamination in the Venice Lagoon and to the set up of a reliable toxicity testing battery for the monitoring. The entire WoE approach will then benefit from the enhanced performances of the "toxicity" LoE.

\section{Acknowledgements}

This work was granted by the ICSEL project promoted by the Ministero delle Infrastrutture e dei Trasporti- Magistrato alle Acque di Venezia through its concessionaire Consorzio Venezia Nuova. The authors are very grateful to Andrea Berton, Emiliano Molin, Matteo Conchetto and Giuseppe Berrelli for sampling sediments. Roberto Cattelan performed total ammonia, sulphide and TOC content analyses.

\section{References}

Aguirre-Martínez, G.V., Owuor, M.A., Garrido-Pérez, C., Salamanca, M.J., DelValls, T. A., Martìn-Díaz, M.L., 2015. Are standard tests sensitive enough to evaluate effects of human pharmaceuticals in aquatic biota? Facing changes in research approaches when performing risk assessment of drugs. Chemosphere 120, 75-85.

Allen, H.E.F., Deng, G.B., 1993. Analysis of acid-volatile sulphides (AVS) and simultaneously extracted metals (SEM) for the estimation of potential toxicity in aquatic sediments. Environ. Toxicol. Chem. 12, 1441-1453.

APAT (Agenzia per la Protezione dell'Ambiente per i servizi Tecnici), 2003. Manual e linee guida 29/2003, vol. 2, pp. 509-524 (in Italian)

ARPAT (Agenzia Regionale per la Protezione Ambientale della Toscana), 2013. Il controllo delle acque di balneazione. Stagione 2013 (67 pp.) (in Italian).

ASTM (American Society for Testing and Materials), 2004. Standard Guide for Conducting Static Acute Toxicity Test Starting with Embryos of Four Species of Saltwater Bivalve Molluscs. E724-98.
Arizzi Novelli, A., Argese, E., Tagliapietra, D., Bettiol, C., Volpi Ghirardini, A., 2002 Toxicity of tributyltin and tripheniltin to early-life stages of Paracentrotus lividus (Echinodermata: Echinoidea). Environ. Toxicol. Chem. 21, 859-864.

Arizzi Novelli, A., Picone, M., Losso, C., Volpi Ghirardini, A., 2003a. Ammonia as confounding factor in toxicity tests with the sea urchin Paracentrotus lividus (Lmk). Toxicol, Environ. Chem. 85, 183-191.

Arizzi Novelli, A., Losso, C., Libralato, G., Tagliapietra, D., Pantani, C., Volpi Ghirardini, A., 2006. Is the 1:4 elutriation ratio reliable? Ecotoxicological comparison of four sediment: water proportions. Ecotox. Environ. Saf. 65, 306-313.

Bat, L., Raffaelli, D., 1998. Sediment toxicity testing: a bioassay approach using the amphipod Corophium volutator and the polychaete Arenicola marina. J. Exp. Mar. Biol. Ecol. 226, 217-239.

Burton, G.A., Chapman, P.M., Smith, E.P., 2002. Weight-of-Evidence approaches for assessing ecosystem impairments. Hum. Ecol. Risk Assess. 8, 1657-1673.

Carballeira, C., De Orte, M.R., Viana, I.G., Carballeira, A., 2012. Implementation of a minimal set of biological tests to assess the ecotoxic effects of effluents from land-based marine fish farms. Ecotox. Environ. Saf. 78, 148-161.

Chapman, P.M., McDonald, B.G., Lawrence, G.S., 2002a. Weight of Evidence frameworks for sediment quality (and other) assessment. Hum. Ecol. Risk Assess. 8, 1489-1516.

Chapman, P.M., Ho, K.T., Munns Jr., W.R., Solomon, K., Weinstein, M.P., 2002b. Issues in sediment toxicity and ecological risk assessment. Mar. Pollut. Bull. 44, $271-278$.

Chapman, P.M., Anderson, J., 2005. A decision-making framework for sediment contamination. Integr. Environ. Assess. Manag. 1, 163-173.

Comrey, A.L., 1973. A First Course in Factor Analysis. Academic Press, New York, U.S. A, p. 316.

Costa, F.O., Neuparth, T., Correia, A.D., Costa, M.H., 2005. Multi-level assessment of chronic toxicity of estuarine sediments with the amphipod Gammarus locusta: II. Organism and population-level endpoints. Mar. Environ. Res. 60 (1), 93-110.

Degetto, S., Cantaluppi, C., Cianchi, A.,Valdarnini, F., 2003. L'arsenico nella Laguna di Venezia. Atti dell'Istituto Veneto di Scienze Lettere ed Arti. tomo CLIX (20002001), pp. 291-328 (in Italian).

DelValls, T.A., Forja, J.M., Gomez-Parra, A., 1999. Sediment quality guidelines in the Gulf of Cadiz: a multivariate approach. Ecotoxicol. Environ. Restor. 2, 34-40.

Fonselius, S., 1969. Hydrography of the Baltic deep basins III. Ser. Hydrogr. Rep. no. 23. Fishery Board of Sweden, Stockholm.

Grant, A., Briggs, A., 2002. Toxicity of sediments from around a North Sea oil platform: are metals or hydrocarbons responsible for ecological impacts? Mar. Environ. Res. 53, 95-116.

ICRAM, 2001. Metodologie analitiche di riferimento Ministero dell'Ambiente e della Tutela del Territorio. Servizio Difesa del Mare (in Italian).

ISO, 2005. Water Quality-Determination of Acute Toxicity of Marine or Estuarine Sediment to Amphipods International Standard Organization 16712 (E)

Kater, B.J., Hannewijk, A., Postma, J.F., Dubbeldam, M., 2000. Seasonal changes in acute toxicity of cadmium to amphipod Corophium volutator. Environ. Toxicol. Chem. 19, 3032-3035.

Lera, S., Macchia, S., Pellegrini, D., 2006. Standardizing the the methodology of sperm-cell test with Paracentrotus lividus. Environ. Monit. Assess. 122, 101-109.

Libralato, G., Avezzù, F., Losso, C., Volpi Ghirardini, A., 2009. Influence of storage methods, refrigeration or freezing, on the toxicity of wastewater samples to oyster embryos. Environ. Technol. 30 (6), 535-541.

Libralato, G., Volpi Ghirardini, A., Avezzù, F., 2010. How toxic is toxic? A proposal for wastewater toxicity hazard assessment. Ecotoxicol. Environ. Saf. 73, 1602-1611.

Long, E.R., MacDonald, D.D., November 16, 1997. Effects range low and median, threshold and probable effects levels. Interactive short course on "use of sediment quality guidelines in the assessment and management of contaminated sediments." In: Proceedings of the 18th Annual Meeting of the Society of Environmental Toxicology and Chemistry (SETAC), San Francisco, CA.

Long, E.R., Ingersoll, C.G., MacDonald, D.D., 2006. Calculation and uses of Mean Sediment Quality Guidelines Quotients: a critical review. Environ. Sci. Technol. 40, 1726-1736.

Losso, C., Volpi Ghirardini, A., 2010. Overview of ecotoxicological studies performed in the Venice Lagoon (Italy). Environ. Int. 36, 92-121.

Losso, C., Arizzi Novelli, A., Picone, M., Marchetto, D., Pessa, G., Molinaroli, E., Ghetti, P.F., Volpi Ghirardini, A., 2004. Evaluation of surficial sediment toxicity and sediment physico-chemical characteristics of representative sites in the Lagoon of Venice (Italy). J. Mar. Syst. 51, 281-292.

Losso, C., Picone, M., Arizzi Novelli, A., Delaney, E., Ghetti, P.F., Volpi Ghirardini, A., 2007a. Developing toxicity scores for embryotoxicity tests on elutriates with the sea urchin Paracentrotus lividus, the oyster Crassostrea gigas, and the Mussel Mytilus galloprovincialis. Arch. Environ. Contam. Toxicol. 53, 220-226.

Losso, C., Arizzi Novelli, A., Picone, M., Marchetto, D., Pantani, C., Ghetti, P.F., Volpi Ghirardini, A., 2007b. Potential role of sulfide and ammonia as confounding factors in elutriate toxicity bioassays with early life stages of sea urchins and bivalves. Ecotox. Environ. Saf. 66, 252-257.

Losso, C., Arizzi Novelli, A., Picone, M., Ghetti, P.F., Volpi Ghirardini, A., 2009. Porewater as a matrix in toxicity bioassays with sea urchins and bivalves: evaluation of applicability to the Venice Lagoon (Italy). Environ. Int. 35, $118-126$.

MacDonald, D.D., Carr, R.S., Calder, F.D., Long, E.R., Ingersoll, C.G., 1996. Development and evaluation of sediment quality guidelines for Florida coastal waters. Ecotoxicology 5, 253-278.

Magistrato Alle Acque di Venezia-Thetis Studio ICSEL, 2006. Rapporto finale sull'attività svolta nel triennio 2003-2006. Prodotto dal Concessionario, Consorzio Venezia Nuova (in Italian). 
Micheletti, C., Gottardo, S., Critto, A., Chiarato, S., Marcomini, A., 2011. Environmental quality of transitional waters: the lagoon of Venice case study. Environ. Int. 37, 31-41.

Phillips, B., Hunt, J.W., Anderson, B.S., Puckett, H.M., Fairey, R., Wilson, C.J., Tjeerdema, R., 2001. Statistical significance of sediment toxicity test results: threshold values derived by the detectable significance approach. Environ. Toxicol. Chem. 20, 371-373.

Picone, M., 2006. Impiego di una batteria di saggi ecotossicologici nel monitoraggio della qualità dei sedimenti della Laguna di Venezia. Use of a Set of Bioassays for Monitoring Sediment Quality in the Lagoon of Venice (Ph.D. thesis). Ca'Foscary University of Venice.

Picone, M., Bergamin, M., Arizzi Novelli, A., Noventa, S., Delaney, E., Barbanti, A., Volpi Ghirardini, A. 2008. Evaluation of Corophium orientale as bioindicator for Venice-Lagoon: sensitivity assessment and toxicity-score proposal. Ecotox. Environ. Saf. 70, 174-184.

Prato, E., Biandolino, F., Libralato, G., 2015. A toxicity scoring system for the 10 days whole sediment test with Corophium insidiosum (Crawford). Environ. Monit. Assess. 187 (180), 11. http://dx.doi.org/10.1007/s10661-015-4405-x.

Redmond, M.S., Scott, K.J., Swartz, R.C., Jones, J.K.P., 1997. Preliminary culture and life-cycle experiments with the benthic amphipod Ampelisca abdita. Environ. Toxicol. Chem. 13, 1355-1365.

Reynoldson, T.B., Smith, E.P., Bailer, A.J., 2002. A comparison of three weight-ofevidence approaches for integrating sediment contamination within and across lines of evidence. Hum. Ecol. Risk Assess. 8, 1613-1624.

Riba, I., Forja, J.M., Gomez-Parra, A., DelValls, T.A., 2004. Sediment quality in littoral regions of the Gulf of Cadiz: a triad approach to address the influence of mining activities. Environ. Pollut. 132, 341-353.

Scarlett, A., Rowland, S.J., Canty, M., Smith, E.L., Galloway, T.S., 2007. Methods for assessing Chronic toxicity of marine and estuarine sediment-associated contaminants using the amphipod Corophium volutator. Mar. Environ. Res. 63, 457-470.

Tay, K.L., Doe, K.G., Wade, S.J., Vaughan, D.A., Berrigan, R.E., Moore, M.J., 1992.
Sediment bioassessment in Halifax Harbour. Environ. Toxicol. Chem. 11, 1567-1581.

Thursby, G.B., Heltshe, J., Scott, K.J., 1997. Revised approach to toxicity test acceptability criteria using a statistical performance assessment. Environ. Toxicol. Chem. 16, 1322-1329.

USEPA, 2001. Method for Assessing the Chronic Toxicity of Marine and Estuarine Sediment-Associated Contaminants with the Amphipod Leptocheirus plumulosus. United States Environmental Protection Agency EPA 600/R-01/020.

USEPA, 2002. Short-Term Methods for Estimating the Chronic Toxicity of Effluents and Receiving Waters to Marine and Estuarine Organisms EPA-821-R-02-014.

USEP, 2005. A Procedure for the derivation of equilibrium partitioning sediment benchmarks (ESBs) for the protection of benthic organisms: metal mixtures (Cadmium, Copper, Lead, Nickel, Silver and Zinc). United States Environmental Protection Agency. EPA 600/R-02/011.

van den Heuvel-Greve, M., Postma, J., Jol, J., Kooman, H., Dubbeldam, M., Schipper, C., Kater, B., 2007. A chronic bioassay with the estuarine amphipod Corophium volutator: Test method description and confounding factors. Chemosphere 66 1301-1309.

Volpi Ghirardini, A., Arizzi Novelli, A., 2001. A sperm cell toxicity test procedure for the Mediterranean species Paracentrotus lividus (Echinodermata: Echinoidea). Environ. Technol. 22, 439-445.

Volpi Ghirardini, A., Losso, C., Arizzi Novelli, A., Baù, A., His, E., Ghetti, P.F., 2005a. Mytilus galloprovincialis as bioindicator in embryotoxicity testing to evaluate sediment quality in the Lagoon of Venice (Italy). Chem. Ecol. 21, 455-463.

Volpi Ghirardini, A., Arizzi Novelli, A., Tagliapietra, D., 2005b. Sediment toxicity assessment in the Lagoon of Venice (Italy) using Paracentrotus lividus (Echinodermata: Echinoidea) fertilization and embryo bioassays. Environ. Int. 31, 1065-1077.

Volpi Ghirardini, A., Arizzi Novelli, A., Losso, C., Ghetti, P.F., Volpi Ghirardini, A., Arizzi Novelli, A., 2005c. Sperm cell and embryo toxicity tests using the sea urchin Paracentrotus lividus (LmK). In: Ostrander, G. (Ed.), Tecniques in Aquatic Toxicology vol.II. CRC press, pp. 147-168, Cap. 8. 